\title{
The Characteristics of Five Food Production Systems and Their Implications for Sustainable Landscapes
}

\author{
Robert P. Burdock ${ }^{1} \&$ Peter Ampt $^{1}$ \\ ${ }^{1}$ Sydney Institute of Agriculture, Faculty of Science, University of Sydney, Australia \\ Correspondence: Robert P. Burdock, Sydney Institute of Agriculture, Faculty of Science, University of Sydney, \\ Australia. E-mail: rob.burdock@sydney.edu.au
}

Received: October 16, 2017

Accepted: December 10, 2017 Online Published: January 15, 2018

doi:10.5539/jas.v10n2p23

URL: https://doi.org/10.5539/jas.v10n2p23

\begin{abstract}
This paper presents a classification of agricultural production systems that we believe characterises the complex interface between agriculture and the landscapes in which they are managed. Farmers have a choice about how they will manage their land, either to exclude inherent environmental complexity or to engage with it, mindful of risks associated with their approach. Adding to this complexity is the interplay between key natural, social, human, physical and financial resources in agricultural systems, highlighting the importance of extending sustainability principles to aspects of ecology, economics and culture. Decisions about agricultural systems hinge on a balance of productive outcomes, on sensitivity to the issues of environmental complexity, on economic grounds including the access to resources, and the socio-cultural needs of the community in which the farmer participates. Further, farm managers will make a choice that both satisfies and suffices (satisfices) against production, ecological efficiencies and resilience outcomes when choosing which food production system to adopt. In this paper, these complexities are analysed against five different agricultural systems on an ecological continuum; from biologically simple industrial systems that minimise interaction with the natural environment, to ecologically complex systems that are closely engaged with their environment. Production viability is a necessary consideration to maintain farming operations but is not sufficient if operational capacity is to be achieved in the long term. This analysis finds that it is also necessary to work with ecological, economic and social complexities, satisficing against productivity, ecological efficiency and inherit system resilience. No one particular farming systems is appropriate in all cases. The farmer's choice may apply a mix of the five different agricultural systems described, allowing for the blending of these attributes in order to sustain rural landscapes.
\end{abstract}

Keywords: agricultural systems, ecological complexity, sustainability, rural landscapes

\section{Introduction}

\subsection{Integrating Ecology and Agricultural Science}

Environmental systems are a set of relationships between agents of the biological community interacting with the climate, topography and geology within a discrete interconnected natural world. Nature can be viewed as a complex system of interacting functionality and feedback loops. Farm systems are managed, open systems with the purpose to transform variable environmental inputs into a satisfactory flow of product (Kaine \& Cowan, 2011). While agriculture is heavily dependent on the natural environment, some agricultural practices succeed through environmental manipulation.

Landscapes are the visible features of an area of land (Oxford English Dictionary, 2016). Often considered in terms of their aesthetic appeal, they are influenced by soil, land use, topography, geography, and weather and climate cycles. Landscapes are varied and have many descriptions including rural, wilderness, urban, coastal, and mountainous. Their description provides a point of reference and sense of place for communities and for the maintenance of culture. At the landscape scale, examples of agricultural practices that manipulate the environment include modifications such as physically altering the landscape as seen with terracing, or via isolation across landscapes such as the use of greenhouses to support a warmer microenvironment.

Ecology deals with complexity ranging from species to populations, to communities, through to ecosystems and landscapes. With increasing levels of integration and interactive complexity is a corresponding decreasing level of scientific understanding (Krebs, 2001). The conversion of the natural environment with its inherent 
self-organising adaptive character, to one that reduces variability through a managed process to maximise the production of a limited number of crops or species, will generally simplify the landscape if a narrower range of fauna and flora is produced. Agriculture disrupts the previously self-organising ecological balance of order and disorder on the landscape (Parrott, 2010). Human intervention, for example, from farming will see complexity reduced towards an ordered regularity. Ongoing management intervention is required to maintain landscape system order with the aim to support food production. A disturbance to the system, for example, from a landslide, will see complexity reduced as a non-ordered regularity is imposed. When the interventions to manage the system are abandoned, landscape complexity will adjust to a point between order and non-order as demonstrated in Figure 1 and Image 1.

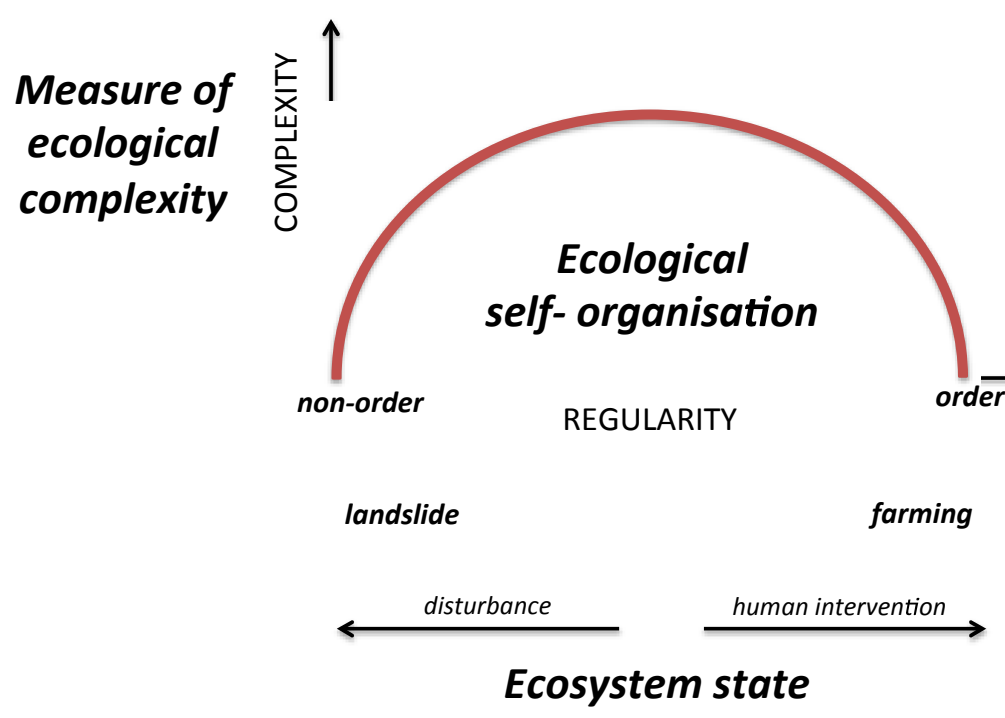

Figure 1. Measure of ecological complexity

A complex adaptive ecological system will find equilibrium of regularity at a satisficed point of higher complexity. A disturbance to the system, for example, from a landslide, will see complexity reduced as a non-ordered regularity is imposed. Human intervention, for example, from farming will see complexity reduced towards an ordered regularity (Adapted from Parrott, 2010). 


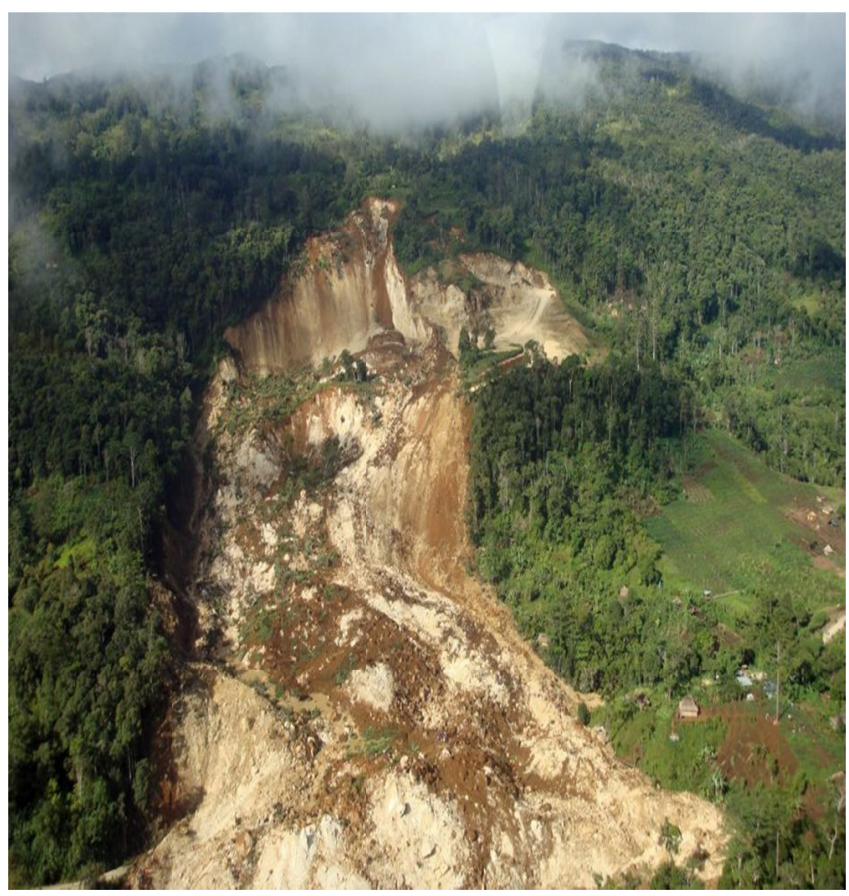

Image 1. Landslide near the Tari farming community in Papua New Guinea's Southern Highlands on 24 January 2012

In the centre of the image, the forest landscape has been disturbed with a landslide. On the right hand side of the image, human intervention in the form of farming has placed order on the landscape. Image, courtesy of the Australian Broadcasting Corporation.

While the disciplines of ecology and agricultural science have been considered as separate specialisations, there is a movement to integrate these areas of study, from soil through to landscapes (Weiner, 2003; Roger-Estrade et al., 2010; Dale et al., 2013). While agriculture itself can be a complicated, even complex activity, what is being discussed here concerns the complexity of living systems on the landscape. The opportunities provided by integrating and applying the findings of systems ecology with farming systems are outlined in the following section.

\subsection{Determination of a Sustainable Food Production Landscape}

The principle of sustainability implies that resources are not used at rates that are greater than the capacity to replace them. The guiding principle of sustainable development is that development meets the needs of the present without compromising the ability of future generations to meet their own needs (Brundtland, 1987). Key resources in agricultural systems include natural, social, human, physical and financial (Pretty, 2008) highlighting the importance of extending sustainability principles to aspects of ecology, economics and culture. The use of non-renewable resources is unsustainable by definition, even if in the short term their consumption contributes to a trajectory toward sustainability (Godfray et al., 2010). Nevertheless, the use of non-renewable resources will likely continue until an economic imperative offers a lower price for a substitutable alternative.

Ecosystem services are the contribution of ecological systems to the production of goods and services that are of value (Dale \& Polasky, 2007). As the demand to increase production approaches the carrying capacity of the landscape and the limits of ecosystem services, the sustainability of rural landscapes is compromised. Within many farming communities, efforts have been undertaken to both pursue sustainable practices and increase production with an eye on the future ability of the land to continue to provide food for the generations to come.

This paper will draw on a background in systems theory to provide an analysis of five different agricultural systems along a continuum in terms of ecological complexity from simple to complex systems in order to assess their contribution to sustainable landscapes. In this analysis it is stressed that systems and policies must be ecologically, economically, and culturally viable, if they are to provide sustainable solutions (Chapin et al., 2009). What is needed is a landscape approach that seeks to find a balance between land use for food production and for 
conservation of biodiversity (Tscharntke et al., 2005). Since agriculture is already placing considerable stress on natural ecosystems, it is timely to reassess what could be considered a sustainable food production landscape.

\section{Five Defined Agricultural Systems}

\subsection{Agricultural Systems, Production Inputs and Economic Theory behind the Five Defined Systems}

In this section agricultural systems are defined and described as human provisioning activities linked to landscapes that are differentiated according to their degree of linkage to and impact on their landscapes over time. All of the systems are currently contributing to the feeding of people. The length of time that an agricultural system has been operating in its landscape is important because that informs sustainability. Long lived systems have traditions that guide interactions between people, practices, inputs, and the landscape that have provided resilience. Newer systems have developed in response to colonisation, the availability of resources and technologies and global demographic and social changes and have not necessarily proven themselves in the long term.

Different methods are first described before their relationship to support sustainable landscapes is examined. How the landscape is managed will define the agricultural system. Methods range in a continuum from simplified intensive mono-cropping through to farming systems incorporating complexity to maximise ecological diversity and the provision of ecosystem services. In between are activities that seek resource extraction with the liberal use of chemicals and efficient feed choice for specifically bred plants and animals, through to a limited use of chemicals and/or soil tillage, to farming methods that mimic and attempt to replicate natural complex systems. For the purposes of this study, agricultural systems are defined at the farm scale in a continuum from an ecologically simplified system, which has a limited interaction with the landscape with a high reliance on external inputs, to ecologically complex systems agriculture that maximises interaction with the landscape. These systems are provided in five categories: industrial, conventional, certified organic, traditional and agro-ecology. In order to set boundaries for this examination, discussion is limited to the farm scale within the context of a broader regional landscape. This is shown in Figure 2.

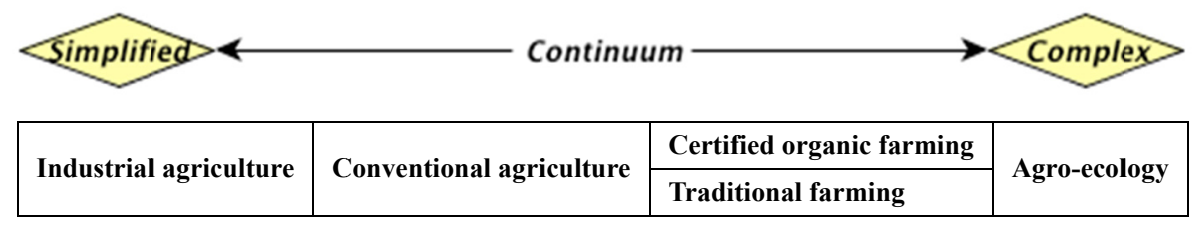

Figure 2. A classification of food production systems on a continuum of increasing ecological complexity

Despite the differences between open agricultural systems and natural ecosystems, they both involve the same biophysical and biological processes and resources, being solar energy, water, soil, and living organisms for biomass production (Malezieux, 2012). These resources are then managed by applying labour, capital, knowledge and methodology to achieve food production.

Economic theory will suggest that production output is a function of a series of inputs, such that:

$$
Q=f\left(X_{1}, X_{2}, X_{3}, \ldots X_{n}\right)
$$

where, $Q$ is the quantity of output and $X_{1} \ldots X_{n}$ are the factor inputs. While quantity produced is a function of a set of inputs, to be economical with resources is to minimise their consumption yet attempt to maximise output.

For farming systems, inputs can be physical and behavioural in order to account for method. The Food and Agriculture Organisation of the United Nations (FAO) uses a total measure of productivity to avoid variations in production systems, be they contemporary or traditional (Zepeda, 2001). These are listed as land, labour, physical capital, livestock and chemical fertilisers and pesticides to determine Total Factor Productivity (TFP), a ratio of an index of agricultural output to an index of agricultural inputs. In order to uniformly examine inputs across different agricultural systems, including those that do not use chemical inputs, these can be organised as soil and nutrient management, animal feeding and management, water management, application of on-farm-capital, energy use, labour, pest and weed management, and landscape impact. Following the descriptions of the five agricultural systems below, a summary of the techniques across the eight input themes is tabulated in Table 1. This is an ecological continuum of landscape simplicity to landscape complexity where boundaries between systems are blurred. 


\subsection{Industrial Agriculture}

Industrial agriculture is characterised by industrial techniques inspired from production engineering, the aim of which is to maximise productivity using principles of industrial efficiency and cost reduction. Two factors differentiate an industrial system. The first is the sheer scale of the operation where the concepts of mass production lower costs and maximise output. The second is that they are independent of many ecosystem services. To manage their size, typically such operations are structured as companies, controlled by professional managers with hired experts, and owned by shareholders who are not directly involved in the running of the business. Off farm inputs are high. Chemicals, fertiliser, fuel for machinery, hired labour, grain to replace pasture for livestock and water are all imported to support operational intensity. Examples of industrial agricultural techniques include cattle rearing through feedlots, battery hens for egg laying, greenhouse production where exposure to the environment and ecosystem services is restricted, and intensively farmed irrigated broad acre cropping. There is a high use of machinery, from seed planting to milk processing. Some practices have been criticised for being harmful to animals, as well as exposing humans and the environment to the risk of chemical contamination (Horrigan et al., 2002; Halteman, 2011; Gagliardi \& Pettigrove, 2013). Some breeding of industrially farmed cattle such as the Belgian Blue for example, has been so intense that in an effort to maximise the meat of the animal, the reproductive functions have been compromised requiring the cow to undergo a caesarean operation to give birth (Wheeler et al., 2003; Bassett, 2009; Kolkman et al., 2010).

Genetically modified organisms (GMO) are organisms and products derived from organisms that are produced through techniques in which the genetic material has been altered in a way that does not occur naturally by mating and/or natural recombination (FAO, 2001a). While GMO and the science supporting it have been controversial (Devos et al., 2008; Waltz, 2009; Bawa \& Anilakumar, 2013), genetic modification has provided pest, herbicide and drought resilient crop varieties (Morris, 2011; Vencill et al., 2012). Although only on the cusp of commercial availability, genetically modified laboratory science has enhanced the genetic improvement of livestock with an aim to further increasing productive output, taste and resistance to disease (Wheeler et al., 2003; McColl et al., 2013; Laible et al., 2015). The use of GMO supports production efficiency by reducing costs and increasing yields.

Industrial agriculture has contributed to food price reduction by using all the benefits of the "green revolution" of selective plant breeding and added soil property enhancements of nitrogen, phosphate and potassium to increase yields and subsequent food supply. Countries which have harnessed their ability to produce food surpluses by employing the methods of industrial agriculture have used their comparative advantage to export produce to nations with a food production deficit relative to the importing country's population needs. When the price of the imported food is lower than that of food that can be grown locally, the small-scale food producers, processors, local traders and consumers are negatively impacted (Windfuhr, 2005).

\subsection{Conventional Agriculture}

Conventional agriculture enjoys high capital investment in the land and in some supporting technologies in order to achieve intergenerational sustainable land stewardship investment. Several farm and production enterprises help to diversify risk. In the developed world, conventional agriculture will foster the availability of ecosystem services and use the technologies provided by precision agriculture. These include chemicals to reduce invasive plants and crop pests, both artificial and natural fertilisers, and natural breeding innovations for livestock (Dale et al., 2013). While some conventional farmers will embrace GMO, others will reject such commitments to avoid both royalties to seed producers and/or to avoid the remotely yet potentially unknown long-term health concerns of society and therefore the market's consequential reluctance to purchase (Morris, 2011). Farm labour can be either hired or extended family members. The degree of farm mechanisation can also vary.

It is in the realm of conventional farming that the blurring of farming methods to achieve sustainable practices is most noticeable, as many conventional farmers will experiment with different farming methods. While farmers tend to be conservative and sceptical about alternative farming methods, when a higher yield can be realised over a longer time frame at a lower cost or with increased benefit, there will be a gradual change in techniques (Pannell, 1999; Klerkx et al., 2010). These include: no-till farming (Montgomery, 2007; Roger-Estrade et al., 2010; Figuerola et al., 2012; Lal, 2013); cycling crop rotations to include nitrogen-fixing plants such as legumes (de Ponti et al., 2012); mixing crops to support natural pest management and integrated pest management using indigenous natural enemies (Watson et al., 2005; Boisclair \& Estevez, 2006; Deguine et al., 2008; Xu et al., 2011); leaving post-harvest crop stubble residue in the soil to reinforce soil structure (Blanco-Canqui \& Lal, 2009); encouraging soil organic complexity (Carter, 2004; Bronick \& Lal, 2005; Barrios, 2007); leaving land to fallow to restore the chemical and biological fertility of the soil (Lal, 2011; Malezieux, 2012); mixed livestock 
and cropping where one compliments the other (Millar \& Badgery, 2009; Fisher et al., 2012); and supporting practices of evergreen agriculture to maintain soil moisture content (Blanco-Canqui \& Lal, 2009; Powlson et al., 2011). Such changes in techniques help to stabilise and increase yields and return carbon to the soil, which further increases yield (Malezieux, 2012). These practices embrace a more sustainable trajectory of landscape stewardship, have the potential to protect against system shocks but, as with industrial agriculture, are still reliant on external inputs to achieve high yields.

\subsection{Certified Organic Farming}

Certified organic farming has a history of regulation (Rigby \& Caceres, 2001; Vogl et al., 2005) with a total of 283 organic certification bodies operating worldwide across 170 countries (Willer \& Lernoud, 2015). It is the inputs and processes that narrowly define organic agriculture along three broad management practices; denial or reduction in the use of chemical pesticides and inorganic fertilisers, sympathetic management of non-cropped habitats, and support to mixed farming practices (Hole et al., 2005). The FAO provides a more detailed definition but follows the three broad themes above. Definitions for organic agriculture can vary across different countries. Biotic pest denial programs are often included, but in the absence of herbicide use, the removal of invasive plant species is more labour intensive. Natural fertilisers are encouraged however, depending on the certifying bodies in various countries, soil fortification is permitted (FAO, 2001b). For meat and dairy products to be certified organic, rules on pasture time remain strict, with the use of growth hormones and antibiotics denied. Organically grown animal feed is required and the application of synthetic fertilisers for that feed is prohibited (Hafla et al., 2013). Depending on the size of the operation, labour can be either hired or can be a mix of owners/families and hired labour. The use of machinery will also be mixed depending on the size and intensity of the organic farm.

Certified organic food production occupies only 1 per cent of global agricultural land with studies and scientific research in organic systems overwhelmingly represented in developed countries. In developing countries, the lack of access to labour markets, storage and distribution infrastructure, certification authorities and insurance can prohibit farmer and scientific collaboration (Willer \& Lernoud, 2015). However, the OECD has found that the variable costs of fossil fuels, irrigation water and other resources can encourage the pursuit of more efficient farming systems (OECD, 2013). With the more efficient use of inputs and lower production costs in organic farming (de Ponti et al., 2012; Seufert et al., 2012) and with a higher price potential for organically certified food, organic farming can be a notably more profitable venture than industrial and conventional agriculture, particularly for smaller farms (Delbridge et al., 2013; Crowder \& Reganold, 2015).

\subsection{Traditional Farming}

Traditional farming systems are systems that demonstrate many centuries of an interactive relationship between communities and their natural landscape, engaging low intensity methods that predate the technologies, breeding varieties and soil enhancing stimulants and plant breeding programs of the "green revolution". There is evidence to suggest that traditional agriculture is generally well integrated with the environment and involves management practices that do not overly exploit the natural carrying capacity of the land (Bignal \& McCracken, 2000; Heckman, 2013). These landscapes are typically organised in a pattern reflecting lower valleys for cropping, slopes for pasture, and hilltops for natural habitat (Fischer et al., 2012). Techniques also follow traditional methods, such as the use of green manures and worm humus for soil fertiliser, the free range grazing of livestock, rain-fed irrigation or channel fed diversion from streams and rivers, the recycling of organic waste, the use of either on-farm livestock or energy dependant machinery for power, and labour from those who live on the farm either as the landowners and their families or as tenant farmers. More than 1.3 billion smallholder farmers in developing countries alone are directly involved in some form of traditional farming (Dasgupta et al., 2014).

\subsection{Agro-Ecology}

While definitions may vary according to different practitioners (Wezel et al., 2014), agro-ecology tends to be based on the application of principles drawn from biology rather than prescriptive recipes of methodology (Rosset et al., 2011). Agro-ecology is a farming method that intentionally includes functional biodiversity across time and space even inviting nature to add plant and animal life to the landscape to maintain biodiversity (Chappell \& LaValle, 2011). Diversity allows for function to be managed. Agro-ecology attempts to mimic nature by incorporating the complexity of natural systems into farming. Trees can be planted with no food crop value, but instead may be carefully selected to attract predator insects, which feed on the insects that eat food crops (Bigger \& Chaney, 1998; Grasswitz \& James, 2009; Woltz et al., 2012). The traded benefit is better recycling of nutrients into the soil, improved soil organic health, lower cost inputs, and produce variety per hectare (Lal, 2011; Altieri et al., 2012). Native ecosystems are time-proven survivors, so it is rational to imitate their useful traits, including their productivity, pest resistance and their ability to conserve nutrients (Ewel, 1999). 
Some prescriptive farming methods such as permaculture are aligned with the principles of agro-ecology (Ferguson \& Lovell, 2014).

As part of the broader landscape, agro-ecology encourages ecosystem services that provide critical inputs to agriculture, such as soil fertility, pest and disease control, water use efficiency, and pollination. Specifically, farmers can: incorporate the use of complimentary functional traits between species to support production and resilience, favouring facilitation rather than competition; maintain soil fertility through soil cover, including tree cover, shading plants to help reduce erosion and moisture loss, and crop rotation; and manage pests by using plant properties and biological alternatives in order to build complexity into the system (Malezieux et al., 2009; Plequezuelo et al., 2009; Garrity et al., 2010; Malezieux, 2012; An et al., 2013). Agro-ecology minimises nutrient losses through a system by recycling biomass, compost and manures into the soil to support healthy soil biology and soil productivity, thus minimising the need for off-farm inputs (Altieri et al., 2012) with the capability to restore severely degraded soils (Holt-Gimenez, 2002; Watson et al., 2005). While there is some mechanisation, rates are low. Because farm lots tend to be smaller, labour tends to be sourced from within a rural community, extended family or in rotational labour sharing from farming cooperatives, rather than from external hire.

Table 1. A summary of inputs to five agricultural systems. This table splits inputs into economic inputs according to a Cobb-Douglas model of the economic production function.

\begin{tabular}{|c|c|c|c|c|c|}
\hline \multicolumn{6}{|c|}{ Comparison of agricultural production systems } \\
\hline Characteristics & Industrial & Conventional & Certified Organic & Traditional & Agro-ecological \\
\hline \multirow{10}{*}{$\begin{array}{l}\text { Soil and nutrient } \\
\text { management }\end{array}$} & \multirow{10}{*}{$\begin{array}{l}\text { Inorganic } \\
\text { fertilisers/hydroponic } \\
\text { s, soil fumigation, } \\
\text { compost from } \\
\text { industrial processes, } \\
\text { manure exported, } \\
\text { little nutrient cycling }\end{array}$} & \multirow{10}{*}{$\begin{array}{l}\text { Inorganic crop } \\
\text { fertilisers, } \\
\text { rotations with } \\
\text { suitable legumes, } \\
\text { pasture phase in } \\
\text { rotation, } \\
\text { occasional green } \\
\text { manure crops }\end{array}$} & \multirow{10}{*}{$\begin{array}{l}\text { Crop rotation, } \\
\text { composting, green } \\
\text { manure crops, } \\
\text { mulching, compost } \\
\text { teas, worm humus } \\
\text { and fluid, animal } \\
\text { wastes composted and } \\
\text { used or sold, soil } \\
\text { biology actively } \\
\text { encouraged. }\end{array}$} & \multirow{10}{*}{$\begin{array}{l}\text { No purchased } \\
\text { fertiliser, } \\
\text { multi-cropping, } \\
\text { crop rotation, } \\
\text { green manure } \\
\text { crops, animal } \\
\text { manures }\end{array}$} & \multirow{10}{*}{$\begin{array}{l}\text { Optimise nutrient cycling } \\
\text { and minimise added } \\
\text { fertilisers, multi-cropping } \\
\text { and rotation especially } \\
\text { with legumes and green } \\
\text { manure crops, use of } \\
\text { perennial plants, } \\
\text { complementary use of } \\
\text { animals. }\end{array}$} \\
\hline & & & & & \\
\hline & & & & & \\
\hline & & & & & \\
\hline & & & & & \\
\hline & & & & & \\
\hline & & & & & \\
\hline & & & & & \\
\hline & & & & & \\
\hline & & & & & \\
\hline \multirow{9}{*}{$\begin{array}{l}\text { Animal feeding } \\
\text { and management }\end{array}$} & \multirow{9}{*}{$\begin{array}{l}\text { Feed imported, } \\
\text { scientifically } \\
\text { determined total } \\
\text { mixed ration, feedlots } \\
\text { and specialised } \\
\text { housing, strict } \\
\text { biosecurity, veterinary } \\
\text { chemicals used }\end{array}$} & \multirow{9}{*}{$\begin{array}{l}\text { Animals mostly } \\
\text { pasture fed, } \\
\text { inorganic } \\
\text { fertilisers, } \\
\text { hand-fed in } \\
\text { drought, limited } \\
\text { stock rotation, } \\
\text { veterinary } \\
\text { chemicals used }\end{array}$} & \multirow{9}{*}{$\begin{array}{l}\text { May graze on pasture } \\
\text { and/or be hand fed, } \\
\text { may be housed, no } \\
\text { un-authorised } \\
\text { veterinary chemicals } \\
\text { eg.no antibiotics }\end{array}$} & Animals graze on & Pasture fed cattle and \\
\hline & & & & existing & sheep, stock rotation to \\
\hline & & & & vegetation and/or & increase perennials and \\
\hline & & & & crop wastes & soil cover, exploit \\
\hline & & & & and/or collected & synergies between \\
\hline & & & & forage, usually & cropping and livestock, \\
\hline & & & & penned or & cultural methods used for \\
\hline & & & & tethered, may be & health with veterinary \\
\hline & & & & shepherded & chemicals as last resort. \\
\hline
\end{tabular}




\begin{tabular}{|c|c|c|c|c|c|}
\hline \multicolumn{6}{|c|}{ Comparison of agricultural production systems } \\
\hline Characteristics & Industrial & Conventional & Certified Organic & Traditional & Agro-ecological \\
\hline Water management & $\begin{array}{l}\text { Irrigation using } \\
\text { sophisticated } \\
\text { scheduling, water } \\
\text { usually diverted } \\
\text { from off-farm } \\
\text { sources, on-farm } \\
\text { water storage and } \\
\text { reticulation, water } \\
\text { management to } \\
\text { maximise profit. }\end{array}$ & $\begin{array}{l}\text { Irrigated and/or } \\
\text { rainfed crops and } \\
\text { pastures, dams to } \\
\text { collect water on-farm, } \\
\text { use of ground water if } \\
\text { available, crop } \\
\text { residues may be } \\
\text { retained, fallow for } \\
\text { water storage. }\end{array}$ & $\begin{array}{l}\text { May be irrigated or } \\
\text { rainfed, attention to } \\
\text { micro-climates. }\end{array}$ & $\begin{array}{l}\text { Rain-fed or small } \\
\text { scale irrigation if } \\
\text { available, usually } \\
\text { gravity fed or using } \\
\text { human labour. Use } \\
\text { of hilling and } \\
\text { trenching, tree } \\
\text { crops interspersed } \\
\text { with annual crops. }\end{array}$ & $\begin{array}{l}\text { May be irrigated or } \\
\text { rain-fed, use of } \\
\text { microclimate } \\
\text { manipulation to reduce } \\
\text { water loss, maximise } \\
\text { perennial and litter } \\
\text { cover, maximise } \\
\text { water-use efficiency } \\
\text { and minimise off-farm } \\
\text { impact. }\end{array}$ \\
\hline $\begin{array}{l}\text { Application of } \\
\text { on-farm capital }\end{array}$ & $\begin{array}{l}\text { High capital } \\
\text { investment in } \\
\text { specialised } \\
\text { technology and } \\
\text { land, high cash } \\
\text { flow due to high } \\
\text { costs and high } \\
\text { returns, use of } \\
\text { credit, economies } \\
\text { of scale. }\end{array}$ & $\begin{array}{l}\text { High capital } \\
\text { investment in land } \\
\text { and some technology, } \\
\text { usually diversified to } \\
\text { several enterprises to } \\
\text { spread risk, use of } \\
\text { credit for purchase of } \\
\text { inputs, owner } \\
\text { manager rarely paid a } \\
\text { salary. }\end{array}$ & $\begin{array}{l}\text { Varying levels of } \\
\text { investment in land } \\
\text { and technology, } \\
\text { may be specialised } \\
\text { or diversified, may } \\
\text { rely on credit to } \\
\text { purchase inputs. }\end{array}$ & $\begin{array}{l}\text { Land often } \\
\text { traditionally owned } \\
\text { and therefore rarely } \\
\text { traded, little access } \\
\text { to credit, reliance } \\
\text { on non-monetary } \\
\text { transactions, } \\
\text { subsistence, sale of } \\
\text { surplus. }\end{array}$ & $\begin{array}{l}\text { Emphasis on managing } \\
\text { and minimising } \\
\text { environmental risk and } \\
\text { market risk, reduced } \\
\text { inputs may be at the } \\
\text { expense of production, } \\
\text { profit considered long } \\
\text { term, ecosystem } \\
\text { services paramount. }\end{array}$ \\
\hline Energy use & $\begin{array}{l}\text { Highly fossil fuel } \\
\text { dependant }\end{array}$ & $\begin{array}{l}\text { Fossil fuel dependant, } \\
\text { some moving to } \\
\text { wind/solar }\end{array}$ & $\begin{array}{l}\text { Some fossil fuel } \\
\text { dependency, may } \\
\text { use more physical } \\
\text { and animal labour }\end{array}$ & $\begin{array}{l}\text { Mostly physical } \\
\text { farm labour and } \\
\text { some animal } \\
\text { labour, little or no } \\
\text { non-renewables }\end{array}$ & $\begin{array}{l}\text { Aim to reduce carbon } \\
\text { footprint, on-site } \\
\text { solar/wind/biogas. }\end{array}$ \\
\hline Labour & Hired farm labour & $\begin{array}{l}\text { Owner-operator, some } \\
\text { hired farm labour, use } \\
\text { of contractors }\end{array}$ & $\begin{array}{l}\text { Owner-operator, } \\
\text { hired farm labour, } \\
\text { volunteers (Willing } \\
\text { Workers On } \\
\text { Organic Farms - } \\
\text { WWOOFers) }\end{array}$ & $\begin{array}{l}\text { Farm families, } \\
\text { increasingly } \\
\text { women, tenant } \\
\text { farmers }\end{array}$ & $\begin{array}{l}\text { Owner operators, } \\
\text { cooperatives. }\end{array}$ \\
\hline
\end{tabular}

\begin{tabular}{|c|c|c|c|c|c|}
\hline \multicolumn{6}{|c|}{ Comparison of agricultural production systems } \\
\hline Characteristics & Industrial & Conventional & Certified Organic & Traditional & Agro-ecological \\
\hline $\begin{array}{l}\text { Pest and weed } \\
\text { management }\end{array}$ & $\begin{array}{l}\text { Chemical, cultural } \\
\text { and genetic } \\
\text { modification, moving } \\
\text { to integrated pest } \\
\text { management (IPM). }\end{array}$ & $\begin{array}{l}\text { Chemical and } \\
\text { cultural. Rarely IPM } \\
\text { as it is highly } \\
\text { specialised. }\end{array}$ & $\begin{array}{l}\text { Reliance on approved } \\
\text { broad spectrum } \\
\text { insecticides and cultural } \\
\text { methods for weed } \\
\text { control, IPM due to few } \\
\text { approved products }\end{array}$ & $\begin{array}{l}\text { Limited use of } \\
\text { insecticides and } \\
\text { herbicides so } \\
\text { yields lower, } \\
\text { reliance on } \\
\text { cultivation for } \\
\text { weed control. }\end{array}$ & $\begin{array}{l}\text { Ecological approach } \\
\text { with IPM, avoid } \\
\text { creating habitat for } \\
\text { weeds by increasing } \\
\text { ground cover and } \\
\text { dominant perennials. }\end{array}$ \\
\hline $\begin{array}{l}\text { Landscape } \\
\text { impact }\end{array}$ & $\begin{array}{l}\text { Production areas } \\
\text { severely modified but } \\
\text { can be small, off farm } \\
\text { impacts due to inputs, } \\
\text { runoff and wastes. } \\
\text { Strong separation of } \\
\text { production and } \\
\text { conservation values. }\end{array}$ & $\begin{array}{l}\text { Production areas large } \\
\text { with varied impact } \\
\text { from moderate to } \\
\text { severe modification, } \\
\text { off farm impacts } \\
\text { mostly due to run-off. } \\
\text { Variable separation of } \\
\text { production and } \\
\text { conservation values. }\end{array}$ & $\begin{array}{l}\text { Production areas varied, } \\
\text { moderate modification, } \\
\text { off farm impacts due to } \\
\text { reliance on organic } \\
\text { inputs, minimal runoff } \\
\text { impacts, integration of } \\
\text { production and } \\
\text { conservation values. }\end{array}$ & $\begin{array}{l}\text { Varied depending } \\
\text { on population } \\
\text { pressure and } \\
\text { climatic } \\
\text { uncertainty. } \\
\text { Conservation } \\
\text { values rarely } \\
\text { emphasised. }\end{array}$ & $\begin{array}{l}\text { Aiming to regenerate } \\
\text { landscapes to renew } \\
\text { range of ecosystem } \\
\text { services, integration } \\
\text { of production and } \\
\text { conservation values. }\end{array}$ \\
\hline
\end{tabular}




\section{System Viability}

\subsection{Sustainability Concepts in Agriculture}

The implications concerning unsustainable practices have been useful for motivating change, however when applied to agriculture, practices to enable change need to be practical. These are characterised as literal, system oriented, quantitative, predictive, stochastic and diagnostic (Hansen, 1996). Any attempt to create sustainable rural landscapes needs to understand and incorporate the properties of measurable complex interactions where functional elements can be identified and any interventions can be predicted to have practical application.

Many definitions for sustainable agriculture follow from the principles of sustainability and sustainable development given earlier (FAO, 2014; USDA, 2007). Some list criteria that, if met, are presumed to meet the definition. These itemise, for example, no chemical contamination of the environment, no soil loss, a limited impact on wildlife biodiversity, and reduced dependence on water and non-renewable resources such as fossil fuel energy and mined phosphate. Other definitions of sustainable agriculture are principle guided, listing prudent use of renewable and/or recyclable resources, and integrating pest management, soil nutrient retention, and minimum tillage to protect the integrity of natural systems. These extend to quality of life improvements for individuals and communities supporting profitable enterprise (FAO, 2014). It is also argued that the principles should not discount the contribution of technologies or practices on ideological grounds, such as incorporating the use of GMO, provided they improve productivity and do no harm to the environment (Pretty et al., 2006). A sufficient definition would define sustainable agricultural systems as those that can nutritionally sustain present societies without denying future generations the same benefits.

Beyond food production is the broader food supply system. Here, consideration is given to food miles (the distance travelled from farmer to consumer); the price paid to the farmer verses the price paid by the consumer to the retailer; the use of energy to produce food; and the involvement of society in the growing, processing and consumption choices of food.

Agricultural systems are best evaluated against a range of environmental, economic and social goals that reflect the view of diverse groups in society through better public policy that does not threaten the integrity of the natural world (Kornegay et al., 2010; Dovers \& Hussey, 2013). Sustainable agricultural systems are thus part of the economic and social development that protects and enhances the natural environment and social equity (Diesendorf, 2000; Pretty, 2008). The US National Academy of Sciences has reported that for any agricultural system to be sustainable it must produce adequate volumes of high-quality food, enhance the natural resource base and environment, be financially viable, and contribute to the wellbeing of farmers and their communities (Kornegay et al., 2010; NRC, 2010; Reganold \& Wachter, 2016). Therefore to achieve sustainable rural and agricultural landscapes, practical applications must integrate elements of production, environmental, economic and socio-cultural viability.

\subsection{Production Viability}

All the systems described in this paper are productively viable. With a focus on productivity, industrial and conventional agriculture tend to out yield certified organic, traditional and agro-ecological systems. The high use of off-farm inputs in industrial and conventional agriculture supports an increase in production over and above the latter systems, which tend to use a higher proportion of on-farm or locally sourced inputs.

Previous reviews of the literature suggest that traditional and certified organic farming production yields average 80 per cent of contemporary conventional agriculture with a large standard deviation of 21 per cent. On-farm nutrient availability and crop rotations with nitrogen fixing crops will influence the variability as will management systems and site characteristics (de Ponti et al., 2012; Seufert et al., 2012). These variations can be as close as 5 per cent for rain-fed legumes and perennials on weak-acidic to weak-alkaline soils, only 13 per cent when best practices are employed in certified organic agriculture and 34 per cent lower on sites where both conventional and certified organic practices are most comparable (Seufert et al., 2012). Another study of 114 small-scale farms across 24 African countries found that traditional farming practices outperformed chemical-intensive conventional farming. In addition, the study found strong environmental benefits such as improved soil fertility, better retention of water in the soil and system resilience to drought (UN, 2008).

In some cases, certified organic agriculture can give a close yield comparison to conventional agriculture, which has controversially contributed to the idea that certified organic and traditional farming methods could substitute for industrial and conventional agricultural systems (Knoblauch et al., 1990; Badgley et al., 2007). Although techniques have improved certified organic farming output in developed countries, certified organic farming alone with its lower production yields is unlikely to witness universal adoption. Based on ninetieth century 
farming methods that were effectively traditional farming systems, production output would have only supported a population of up to 4 billion (Connor, 2008).

The careful application of traditional farming and agro-ecology has the ability to increase yields in developing countries. To explore this, a study was conducted of 286 agricultural sustainability projects using traditional systems across 57 developing countries. These countries were predominantly in Latin America, Africa and Asia, and involved 12.6 million chiefly smallholder farmers on a total of 37 million hectares, which is a land footprint slightly larger than Germany. The study found an average yield increase of 79 per cent across a very wide variety of systems and crop types. One-quarter of the projects reported a doubling of yield (Pretty et al., 2006).

Comparing developed world studies with developing world studies can be problematic. Studies by proponents of agro-ecology suggest that agro-ecology, as practiced in peasant communities in the developing world, particularly in Latin America, can out-yield conventional monocultures yet recognise that in the wealthier developed world, farmers using slower responsive traditional farming practices such as measured biological pest control techniques will not be in a position to compete with the application of more immediate chemical pest controls used in conventional systems (Rosset et al., 2011; Altieri et al., 2012).

Three years is an accepted period of time required to switch to a certified organic system of food production (Dimitri \& Oberholtzer, 2009; ACOS, 2013). During any transition period to a traditional, certified organic, or agro-ecological system, productivity is expected to be low. While this is often attributed to an adjustment in soil health to an improving microbiological community (Tu et al., 2006; Leithold et al., 2015), there is evidence to suggest that it is not just soil that assists in greater yields over time, but also applied management techniques (Martini et al., 2004).

\subsection{Environmental Viability}

In order to qualify as sustainable, open farming systems must be environmentally viable and enhance the resource base, particularly in relation to ecosystem services. Agriculture benefits from ecosystem services, but to encourage a stabilising feedback relationship with its environment, ideally it should also contribute to ecosystem service provision at both a landscape level, and particularly in terms of soil management.

Soil is likely the most complex biological community (Barrios, 2007; Havlicek, 2012). Vegetation cover and surface leaf-litter shields the soil environment from the effects of direct raindrop impact, of water moving over the landscape, from wind that can dry out then blow loose soil from the landscape, and from direct baking sunlight (Abel et al., 1997; Helfrich et al., 2008; Villegas et al., 2010). Vegetation cover helps to give soil its structure (Nielsen et al., 2011) enabling soil microbial activity to thrive (Plequezuelo et al., 2009; An at el., 2013; Fanin et al., 2014) creating a feedback loop by enhancing soil's ability to support plant growth. The healthier the soil microbial community, the healthier the environment in which plants can prosper (Schmidt et al., 2011; Singh et al., 2011).

Although soil communities may be robust, relationships between diversity and stability need to be considered in developing a predictive understanding of the response to environmental shocks (Girvan et al., 2005). If the desire is to achieve the highest possible yield in the short term, crops will require high volumes of off-farm fertiliser. This imbalance of additional phosphate and nitrogen tends to switch off microbial facilitated input and cycling activities that contribute to the symbiotic relationship with root nodules, mycorrhizae (fungal and plant root interaction), and proteoid roots (cluster roots that enhance nutrient uptake). Over time, this degrades soil's natural productivity. If the resilience and efficiency of a natural system are to be imitated, unnaturally high nutrient inputs will need to be reduced, resulting in a less productive but a more biologically sustainable yield (Ewel, 1999).

Preserving the integrity of natural systems extends beyond soils to landscapes. Encouraging an interactive natural environment with agriculture, either with intercropping or incorporating natural and farming landscapes, has been identified as an opportunity for further research (Letoureau \& Bothwell, 2008). Such practices maintain and sustain landscapes to support on-going production (Wratten et al., 2012; Woltz et al., 2012). For example, progressive farmers will keep some land as a natural landscape to support bees and predator insects. Bee populations and other pollinators will naturally help to pollinate crops (Kevan \& Phillips, 2001; Kremen et al., 2002; Brown \& Paxton, 2009). Where biological diversity in the insect population can co-exist, predator insects can be used instead of insecticides to consume those insects that are attracted to crops (Boisclair \& Estevez, 2006; $\mathrm{Xu}$ et al., 2011). The higher prices charged for certified organic produce is often justified on the basis that financial flows to farmers is in part to compensate for the maintenance of ecosystem services or avoiding techniques which damage natural ecosystems (Reganold \& Wachter, 2016). 


\subsection{Economic Viability}

While an agricultural system must be mindful of the environment in which it sits, it is important to note that there is a difference between productive viability and economic viability. The dynamics of fragile rural economies are at risk, as is the continuing degradation of existing farmland from intensive practices (Das, 2002; Cullather, 2010). As less labour is required on the farm, fewer services are required in rural societies, which contribute to rural depopulation (Hamblin, 2009; Berglund et al., 2014). While a system such as industrial and conventional agriculture employs fewer people and achieves a higher productive capacity, alternative systems and approaches can offer stronger economic credentials. As such, maximising profit per hectare is a better goal for the farmer than to maximise production (Gardiner \& Reid, 2010).

The profitability of certified organic systems as alluded to earlier is worthy of further attention. Factors that increase the costs of certified organic farming include the cost of additional labour intensity, the reduction of income during the three-year transition period, and the lower yields achieved when compared with industrial or conventional yields. To their benefit, farmers of certified organic produce can charge a price premium and save on input costs via the reduced reliance on non-renewable resources and off-farm inputs (Reganold \& Wachter, 2016). Research combining the findings from 40 years of studies covering 55 crops across five continents concluded that despite its lower yield output and not accounting for externalities or ecosystem services, certified organic farming was significantly more profitable than conventional agriculture by a factor of between 22 to 35 per cent (Crowder \& Reganold, 2015). Another review of 88 studies with 458 data pairs found that while yields could be higher, gross margins for certified organic farmers in mostly developed countries were 51 per cent higher (Te Pas \& Rees, 2014).

\subsection{Socio-Cultural Viability}

Following the end of World War II, the shift towards industrialisation of agricultural activities has witnessed greater mechanisation to replace human labour, intensification associated with an increase of product per hectare, and specialisation in cropping or animal production. These developments have been underpinned with improvements in science and technology. By streamlining agricultural techniques along the practises of industrial efficiency, processes and techniques have led to standardisation, which has led to a loss of farm and landscape diversity, which has reduced resilience. New science and technology is called upon to find solutions (Hardeman \& Jochemsen, 2012). Specialisation in agriculture has required genetic manipulation to maximise production and resistance to disease and insect predation to support broad scale agriculture. The build-up of herbicide and pesticide residues in humans has triggered health concerns (Smith-Spangler, 2012; Vieweger \& Doring, 2015). The increase in the scale of agriculture has created oversupply, making food cheap and undervalued in industrial societies with a reduced financial return to farmers, thus threatening their livelihood. Farming is a distinct socio-economic sector where the impact of the application of industrial processes has been overlooked (Hardeman \& Jochemsen, 2012).

In this historical context, the value of socio-cultural viability to achieve sustainable rural and agricultural landscapes has been underestimated. Legal systems support individual property rights and intellectual property rights over the rights of communities as a whole (Hamblin, 2009). This has been evident, for example, in South Africa where communities struggle to protect issues of collective ownership (Thornton, 2009; Bennett et al., 2010), and in Latin America where with little compensation, the scientific community exploits the knowledge of indigenous communities, which has been acquired over millennium (Zerda-Sarmiento \& Forero-Pineda, 2002). The scientific research and attention being given to Australian native rice, which was domesticated by Australia's Aboriginal people over thousands of years, follows a similar theme (Pascoe, 2014).

In rural communities, farming remains a way of life as the basis of employment identity, cultural anchoring, and social cohesion. In developed countries, the adoption of industrially efficient processes, scientifically proven techniques, and technologically engaged machinery has removed much of the socio-cultural fabric of rural life as rural areas continue to depopulate (Hamblin, 2009; Berglund et al., 2014). There is a risk that socio-cultural issues can be forgotten on ideological grounds in the drive to production efficiency (Hardeman \& Jochemsen, 2012).

On a positive note, the socio-cultural viability on communities of certified organic and traditional farming has led to an increase in economic development and, through direct contact between farmers and consumers, particularly at farmers' markets, has fostered greater civic participation, higher levels of volunteerism, and engagement in local politics (MacRae et al., 2007; Goldberger, 2011; Obach \& Tobin, 2014). Certified organic farming, with its higher use of labour, has supported rural employment and increased cooperation between farmers (Halloran \& Archer, 2008; Reganold \& Wachter, 2016). Farmers in poorer nations also benefit when 
their certified organic produce is exported to wealthier nations in Europe and North America who are willing to pay a price premium on certified organic food. The downside of pursing this export opportunity is that it risks denying local consumers from being able to purchase these foods. This has an impact on the socio-cultural viability of these communities (Willer \& Lernoud, 2015; Reganold \& Wachter, 2016).

While industrial agriculture has arguably taken the community out of food production (Bignal \& McCracken, 2000), traditional farming and agro-ecology are culture centric. Traditional farming systems tend to be structured for social outcomes, supporting a way of life in traditional rural communities; for example for community cohesion in Mexico (Pulido \& Bocco, 2003), infusing religion and tradition in Syria (Alhamidi et al., 2003) or with support for a more traditional lifestyle to achieve ecosystem services for human wellbeing in developed countries in Scandinavia and Japan (Berglund et al., 2014). The European Union (EU) for example, encourages farmers to conserve biodiversity by engaging in a minimum five-year program to protect and enhance the environment on their farmland. Under the EU's Common Agricultural Policy, the Agri-Environmental Program subsidises farmers for the provision of environmental services, including integrated farm management and organic agriculture. This extends to the preservation of landscape and historical features such as hedgerows, ditches and woods in order to meet a social demand for environmental outcomes provided by agriculture. Twenty-two per cent of the expenditure for rural development in the EU is associated with this program (EU, 2015). Although there is an acknowledged community preference for maintaining traditional farming landscapes (Kaltenborn \& Bjerke, 2002; Howley et al., 2012), maintaining traditional farming as an aesthetic benefit with its perceived connection with nature has been criticised as being an expensive luxury in developed countries when productive output is low and government subsidies are required to maintain the landscape (Fischer et al., 2012).

The attributes of agro-ecology are rated highly for socio-cultural viability. It is akin to the targeted social outcomes of traditional farming where the sharing of knowledge between farmers contributes to a collective future. It is based on social processes that value community participation and community-oriented outcomes, which promote self-reliance, cooperation, and empowerment to meet regional food needs (Altieri \& Toledo, 2011). Based on the principles and science of ecology, agro-ecology is a social movement taking concepts of food security to food sovereignty where the broader community participates in the food production system. Agro-ecology has been used to facilitate system change when coupled with an understanding of how change occurs in society (Gliessman, 2013).

So important is the socio-cultural viability of agriculture that some urban neighbourhoods, far removed from any form of food production, have sought to come together to create a greater sense of local community around agriculture. Community supported agriculture, where urban food gardens are jointly farmed by the local residents, is an attempt for socially isolated city-dwellers to reconnect with society through farming (Anderson, 2008; Sumner et al., 2010; Alkon \& Mares, 2012).

\section{A Broader Landscape Perspective}

\subsection{Satisficing for Productivity, Efficiency and Resilience}

Stability refers to the tendency of a system to return to a position of equilibrium when disturbed (Ludwig, 2002). The relationship, or trade-off, among the attributes of resilience, efficiency and productivity to achieve stability is a key feature of dynamic self-organising complex systems. To satisfice, refers to the activity within a system that both satisfies and suffices (Simon, 1957; Brown, 2004). Thus, the interactions of the system with the external environment will determine how productivity, efficiency and resilience are satisficed, that is, to be sufficiently balanced to satisfy on going stability. Some farmers are shifting to a more holistic land management orientation in order to improve productivity, to work more efficiently with nature, and to build in resilience to shocks, demonstrating that to trade between productivity, efficiency and resilience is not a zero-sum gain (Glendining et al., 2009). At play is the attempt to collectively satisfice these properties.

The move from traditional farming systems to industrial and conventional systems in the last half-century has witnessed a quest for higher yields, emphasising the pursuit of productivity over efficient cooperation with natural systems and the inherent resilience in complex systems. These issues raise questions concerning the sustainability of landscapes to support continued intensive food production activity (Filson, 2004; Borlaug, 2007; Gibson et al., 2007; Gomiero et al., 2011).

There are two reasons why it is unlikely that the precise mimicking of natural ecosystems will produce the yields in farming systems that incorporate complexity as the high yield achieved by conventional and industrial agriculture. The first is that the bulk of the biomass in natural systems plays a role in sustaining the protective structure of the ecosystem. To harvest significantly from the system is to deviate from the order of the natural structure and risk the system's resilience. The second reason for potentially lower yields concerns the presumed evolutionary trade-off 
between reproduction and permanence (Ewel, 1999). Yet there is evidence, as provided earlier, to suggest that a high level of productivity can be achieved from farming which follows the principles of complex systems oriented agriculture.

Efficiency in the context of a complex system can be viewed as the energy utilised by the system as a fraction of the incident energy (Butzer \& Endfield, 2012). Thus, efficiency is defined as the lowest quantity of energy (effort) input to create the greatest quantity of output. This definition of efficiency in an agricultural context can be contentious. Is it efficient to simplify the farming process, allowing for straightforward yet repetitive tasks to be applied to a broader landscape to create process efficiencies, or is it efficient to work with nature by building in landscape complexity, allowing the farmer to "tinker" with cooperative ecological efficiencies to support production? Until recently, conventional agricultural processes which encompassed those of the green revolution, were judged efficient by the theories of economic and industrial optimisation aimed at maximising short-term yields and profits (Weiner, 2003). Ecological energetics suggests a relationship between energy returned on energy invested (EROEI) (Tomlinson et al., 2014). For the purposes of this discussion, the application of efficiency is related to the effort required to maintain the farming system as an ordered system against the tension with natural ecological energetics, which moves the system towards ecological complexity.

For managed landscapes, resilience can be observed when the system is managed by robust practices that demonstrate capacity to recover from disturbances or unanticipated surprises, retaining its basic structure and viability (Foley et al., 2011; Walker \& Salt, 2012). The preservation of ecosystem complexity and function in managed landscapes can in many cases aid in mitigating the effects of extremes in weather, and enhancing vital services such as water retention. For example, evergreen agriculture, which involves the integration of trees into annual food crop systems throughout the year, provides a relationship between vegetation functionality and the variance of surface temperature. This indicates a positive correlation between complex biodiversity and dissipative capacity of incoming stress, in this example, from heat from direct sun exposure (Schneider \& Kay, 1994; Garrity et al., 2010; Norris et al., 2012).

\subsection{Maintaining Agricultural Harmony in Landscapes}

There is no doubt that the adoption of what has become traditional agriculture has replaced what was once a natural environment. It is possible however for agricultural activities to increase landscape biodiversity, and diverse examples over several millennia can be found in the Mediterranean basin, in the Chihuahuan Desert in in Mexico, and in Australia. Around the Mediterranean, farming activities have increased the biodiversity of the landscape to a greater degree than likely existed when the landscape was in its original oak woodland character at the commencement of the Holocene (Blondel, 2006). Indeed, one recent study has found in a mountain area near metropolitan Barcelona, Spain. The abandonment of traditional farm land, where peasant farmers once shaped the capacity of the landscape to host biodiversity, has seen the transition to a forested landscape lose its biodiversity (Otero et al., 2015). A further example can be found in Chihuahuan Desert in Mexico, a region now engaged in traditional agriculture. The increase in biodiversity from farming is evident from the paleontological record in the changing vegetation and loss of mega-fauna in the last 10,000 years to the pre-Columbian landscape (Janzen, 1986). Similar paleontological and archaeological records have been found in Australia where the loss of mega-fauna and evident human intervention has changed the natural landscape over the last 40,000 years as Aboriginal Australians modified the environment to provide a park-style landscape to provide abundant food resources for ease of hunting, gathering, and farming (Flannery, 1994; Gammage, 2011; Pascoe, 2014).

Traditional farming is still practiced in many developing countries where the cost to do otherwise is prohibitive and existing practices have been sustained for many generations. In some developed countries, traditional farming is viewed as a lifestyle choice, often willingly supported with public funds to maintain a "cultural" landscape seen to be in harmony with nature (Berglund et al., 2014). Nevertheless, there is an element of resilience at work with traditional farming systems. By remaining within the natural carrying capacity of the landscape and staying well below the thresholds of production or efficiency frontier possibilities, natural complexity interactions are free to act within managed boundaries.

\subsection{Setting Landscapes Aside for Conservation}

Land sparing for conservation, the aim of which is to separate agricultural land from land set aside for biodiversity conservation, may be defined as high yielding food production on a small land footprint. Land sharing for conservation, the aim of which is to share agricultural land with land set aside for biodiversity conservation, may be defined as low yielding, wildlife-friendly food production on a large land footprint (Kremen, 2015). Although agro-ecology is ideally placed to incorporate wildlife-friendly farming (Kremen, 2015), some conventional farmers are preserving and even integrating some areas for natural wildlife in order to 
broaden biodiversity with an eye to intergenerational landscape management (Scherr \& McNeely, 2008). The agricultural intensification and land-sparing relationship is an important priority for sustainability science (Rudel et al., 2009).

The EU's Agri-Environmental Program cited earlier encourages environmentally favourable extension of farming, management of low-intensity pasture systems, and conservation of high-value habitats and their associated biodiversity (EU, 2015a). One quarter of farmers in Australia are incorporating vegetation management to include either the planting of, or encouraging the regrowth of native vegetation, with 20 per cent of respondents fencing native vegetation to prevent degradation (ABARES, 2014). While there is some complimentary benefit to preserve natural habitat adjacent farming land, there will be a loss of farm productivity. A study in southwest Ghana and northern India found that when sharing agricultural land for biodiversity conservation, more species where negatively affected by agriculture than benefited from it. Land sparing was found to be a better alternative for both agricultural yields and biodiversity conservation (Phalan et al., 2011). A UK study on a single crop type of winter cereals has suggested that biodiversity conservation efforts are best focussed on low-productivity agricultural systems or land not suitable for agriculture (Gabriel et al., 2013).

\subsection{Integrating and Enhancing Landscapes}

Definitions of sustainability are outcomes oriented. Many farmers employing conventional agricultural practices are adopting sustainable practices by recognising soil microbial dynamics, minimising soil disruption with minimal or no-till seed planting, rotating crops to ensure nitrogen-fixing plants replenish nutrients, giving up productive land to plant trees to act as wind breaks, and employing drip irrigation to conserve water resources. For example, a 2009 survey of US farmers found that 60 per cent of respondents were undertaking various forms of sustainable farming, with 50 per cent using no till farming techniques and 45 per cent using a form of crop rotation or crop diversification strategies (RaboBank, 2009). More recently, the Australia report cited above found that 66 per cent of respondents were engaging in minimum tillage or cultivation and that 55 per cent were using cover crops, inter-row crops or mulching techniques, with 80 per cent incorporating organic matter to enhance soil fertility (ABARES, 2014).

The narrow scope of certified organic farming, defined only by its inputs (or absence of certain inputs), prohibits this system as being automatically defined as sustainable. However, recent studies suggest that certified organic farming has a positive effect on biodiversity compared with conventional farming, particularly in homogeneous landscapes, but the effect size varies with the species group and the crop studied. It depends on the type of landscape surrounding the farm. As an example, certified organic farming increases bee diversity by enhancing flower availability when influenced in a landscape context (Kremen et al., 2002; Holzschuh et al., 2007). The biodiversity gains are typically found locally but studies reveal little about contributions to regional biodiversity conservation with the impact being greater in landscapes with higher land-use intensity than those supporting less intensive land-use methods (UN, 2005; Gomiero et al., 2011; Winqvist et al., 2012; Schneider et al., 2014; Tuck et al., 2014).

What is surprising is the finding that the yield from integrating plant species verses a mono-cropping approach, produces a harvest over time that is only marginally below that produced by conventional systems, without trading resilience. These results have been found from practices in countries such as Cuba, Brazil, the Philippines and the African countries of Zambia, Malawi, Niger, and Burkina Faso (Garrity et al., 2010; Altieri et al., 2012). Thus, when agriculture is viewed as applied ecology, this shifts perspectives to see agricultural strategies in terms of trade-offs rather than improvements (Weiner, 2003). The philosophy of integrated farming contributes to these effects as complexity is built into farming systems by mimicking nature (Roling \& Wagemakers, 1998; Lemaire et al., 2014). Such an approach would suggest integrating and enhancing landscapes may trade-off some productivity in the short term, but will lead to more sustained production in the long term. Certainly, the ecological management of agro-ecosystems that addresses energy flows, nutrient cycling, population-regulating mechanisms and system resilience can lead to the redesign of agriculture at a landscape scale (Pretty, 2008).

\section{Discussion}

As well as being productive, agriculture must be ecologically, economically, and culturally viable (Chapin et al., 2009). The food production systems described here: industrial agriculture, conventional agriculture, certified organic farming, traditional farming and agro-ecology; have varying yields of productive output according to their farming techniques and the application of the five input factors of soil, water, capital, energy and labour. Yet not all these systems will support sustainable rural and agricultural landscapes when environmental, economic and socio-cultural viability must also be considered. 
Industrial agriculture will maximise production utilising concepts of industrial efficiency with less consideration of landscape resilience or environmental impact. Conventional agricultural practices continue to adapt to incorporate environmentally sensitive practices to minimise ecosystem disturbance with a view to maintaining productive output. Certified organic and traditional farming have also been shown to contribute to positive environmental and ecosystem outcomes but have gone further to demonstrate an increase in socio-cultural viability. Certified organic farming in particular has been shown to be economically beneficial with higher profits on a lower yield threshold when compared with conventional agriculture. Agro-ecology sets out in the first instance to achieve environmental and socio-cultural viability yet produce sufficient yield output to remain productively viable.

From a landscape perspective, those systems which tend to integrate natural systems such as traditional farming and agro-ecology will contribute to a sustainable landscape environment with a minimum of human effort against ecosystems that naturally incorporate more complexity. At only 1 per cent of global agricultural land use, there is also an opportunity for greater application of certified organic farming techniques, particularly when certified organic farming has been identified as a better contributor to human health, the environment, farmer profitability and socio-cultural cohesion (Crowder \& Reganold, 2015). However, with organic farming's lower productive output and the need to feed more than 7 billion people, it would be naïve and simplistic to suggest that the entire globe should ignore the benefits of the productive output from conventional and industrial agriculture.

Even though approximately one-third of all the edible food produced is never consumed (FAO, 2011), the demand on food systems is set to increase, giving impetus to highly productive systems. Sustainable conventional agriculture may be a necessary compromise. When farming techniques substitute for the shortfalls in the self-organising complex adaptive character of natural systems by integrating and enhancing natural systems to create harmony with landscapes, landscapes can remain sustainable provided human intervention remains alert to system stability. Landscape sustainability is improved when conventional agriculture, with its higher productive output, sets aside land for conservation and better targets the use of water, fertiliser and pest controls.

It is no coincidence that the adoption of agricultural systems that rely heavily on external inputs such as industrial and conventional agriculture are the systems most observed in developed countries where the broader economy is more complex, labour costs are high, supply chains are reliable, and financial transactions are facilitated with technology and given the protection of the law. Traditional farming and agro-ecology has been a successful choice for food production in countries where the supply of external inputs is unreliable, labour costs are not prohibitive, freight and transport is expensive, the lack of cold storage encourages food to be consumed soon after harvest or slaughter and closer to where it is produced, where rural populations support social cohesion, and where the long term viability of natural systems are essential to nurture and support the inputs used for local food production.

\section{Conclusion}

When production, environmental, economic and social viability interplay, there is no single global sustainable agricultural solution to achieve and maintain sustainable landscapes. Proposed is a combination of all the types of agriculture, blending the best of the agricultural systems and of environmental conservation, encouraging debate on "terraculture", defined as farming for a whole planet (Foley et al., 2011). This would include a blend of certified organic and other innovative farming systems such as integrated farming techniques, mixed crop and livestock, hybrid organic-conventional agriculture, grass-fed livestock production, and systems yet to be trialled, to offer a better landscape solution (NRC, 2010; Leifeld, 2012; Reganold \& Wachter, 2016). To some extent, conventional agriculture in developed countries is embracing these methods. This direction takes a complex systems approach that seeks productive outcomes with efficiency in working with nature, which supports resilience to unexpected weather events or supply chain disruption. In the long run, the farmer's choice to determine which food production system to adopt will hinge on a balance of productive outcomes, on sensitivity to the issues of environmental complexity, on economic grounds including the access to resources, and the socio-cultural needs of the community. A mix of all these attributes will be needed to support sustainable rural landscapes.

\section{References}

ABARES. (2014). Drivers of practice change in land management in Australian agriculture, Synthesis report-Stages I, II, and III. Australian Department of Agriculture and Water Resources. Australian Bureau 
of Agriculture and Resource Economics and Sciences. Retrieved October 16, 2017, from http://data.daff. gov.au/data/warehouse/9aah/2014/DrvPracChngLndMan/DrvPracChngLndMan20140626v1.0.0.pdf

ACOS. (2013). Australian Certified Organic Standard 2013. Australian Organic Limited. Retrieved October 16, 2017, from http://austorganic.com/wp-content/uploads/2013/11/ACOS-2013-final.pdf

Alhamidi, S. K., Gustafsson, M., Larsson, H., \& Hillbur, P. (2003). The cultural background of the sustainability of the traditional farming system in the Ghouta, the oasis of Damascus, Syria. Agriculture and Human Values, 20(3), 231-240. https://doi.org/10.1023/A:1026123929170

Alkon, A. H., \& Mares, T. M. (2012). Food sovereignty in US food movements: Radical visions and neoliberal constraints. Agricultural Human Values, 29(3), 347-357. https://doi.org/10.1007/s10460-012-9356-Z

Altieri, M. A., \& Toledo, V. M. (2011). The agroecological revolution in Latiin America: Rescuing nature, ensuring food sovereignty and empowering peasants. The Journal of Peasant Studies, 38(3), 587-612. https://doi.org/10.1080/03066150.2011.582947

Altieri, M. A., Funes-Monzote, F. R., \& Petersen, P. (2012). Agroecologically efficient agricultural systems for smallholder farmers: Contributions to food sovereignty. Agronomy for Sustainable Development, 32(1), 1-13. https://doi.org/10.1007/s13593-011-0065-6

An, J., Zheng, F. L., Romkens, M. J. M., Li, G. F., Yang, Q. S., Wen, L. L., \& Want, B. (2013). The role of soil surface water regimes and raindrop impact on hillslope soil erosion and nutrient losses. Natural Hazards, 67(2), 411-430. https://doi.org/10.1007/s11069-013-0570-9

Anderson, M. (2008). Rights-based food systems and the goals of food systems reform. Agriculture and Human Values, 25(4), 593-608. https://doi.org/10.1007/s10460-008-9151-z

Badgley, C., Moghtader, J., Quintero, E., Zakem, E., Chappell, M. J., Aviles-Vazquez, K., ... Perfecto, I. (2007). Organic agriculture and the global food supply. Renewable Agricultural Food Systems, 22(2), 86-108. https://doi.org/10.1017/S1742170507001640

Barrios, E. (2007). Soil biota, ecosystem services and land productivity. Ecological Economics, 64(2), $269-285$. https://doi.org/10.1016/j.ecolecon.2007.03.004

Bassett, A. (2009). Welfare and Belgian Blue Cattle. Animal Welfare Approved Technical Advice Fact Sheet No. 1. Animal Welfare Approved. Retrieved October 16, 2017, from https://animalwelfareapproved.us/ wp-content/uploads/2013/07/TAFS-1-Welfare-and-Belgian-Blue-Cattle-v1.pdf

Bawa, A. S., \& Anilakumar, K. R. (2013). Genetically modified foods: Safety, risks and public concerns-A review. Journal of Food Science Technology, 50(6), 1035-1046. https://doi.org/10.1007/s13197-012-0899-1

Bennett, J., Ainslie, A., \& Davis, J. (2010) Fenced in: Common property struggles in the management of communal rangelands in central Eastern Cape Province, South Africa. Land Use Policy, 27(2), 340-350. https://doi.org/10.1016/j.landusepol.2009.04.006

Berglund, B. E., Kitagawa, J., Lageras, P., Nakamura, K., Sasaki, N., \& Yasuda, Y. (2014). Traditional Farming Landscapes for Sustainable Living in Scandinavia and Japan: Global Revival through the Satoyama Initiative. AMBIO, 43(5), 559-578. https://doi.org/10.1007/s13280-014-0499-6

Bigger, D. S, \& Chaney, W. E. (1998). Effects of Iberis umbellata (Brassicaceae) on insect pests of cabbage and on potential biological control agents. Environmental Entomology, 27(1), 161-167. https://oi.org/10.1093/ ee/27.1.161

Bignal, E. M., \& McCracken, D. I. (2000). The nature conservation value of European traditional farming systems. Environmental Reviews, 8(3), 149-171. https://doi.org/10.1139/a00-009

Blanco-Canqui, H., \& Lal, R. (2009). Crop Residue Removal Impacts on Soil Productivity and Environmental Quality. Critical Reviews in Plant Sciences, 28(3), 139-163. https://doi.org/10.1080/07352680902776507

Blondel, J. (2006). The "Design" of Mediterranean Landscapes: A Millennial Story of Humans and Ecological Systems during the Historic Period. Human Ecology, 34(5), 713-729. https://doi.org/10.1007/s10745006-9030-4

Boisclair, J., \& Estevez, B. (2006). Insect pest management in organic agriculture: Acting in harmony with complexity. Phytoprotection, 87(2), 83-90. https://doi.org/10.7202/013977ar

Borlaug, N. E. (2007). Feeding a hungry world. Science, 318(5849), 359-359. https://doi.org/10.1126/ science. 1151062 
Bronick, C. J., \& Lal, R. (2005). Soil structure and management: A review. Geoderma, 124(1-2), 3-22. https://doi.org/10.1016/j.geoderma.2004.03.005

Brown, M. J. F., \& Paxton, R. J. (2009). The conservation of bees: A global perspective. Apidologie, 40(3), 410-416. https://doi.org/10.1051/apido/2009019

Brown, R. (2004). Consideration of the origin of Herbert Simon's theory of "satisficing" (1933-1947). Management Decision, 42(10), 1240-1256. https://doi.org/10.1108/00251740410568944

Brundtland, G. H. (1987). Report of the World Commission on Environment and Development: Our Common Future. Retrieved October 16, 2017, from http://www.un-documents.net/our-common-future.pdf

Butzer, K. W., \& Endfield, G. H. (2012). Critical perspectives on historical collapse. Proceedings of the National Academy of Sciences, 109(10), 3628-3631. https://doi.org/10.1073/pnas.1114772109

Carter, M. R. (2004). Researching structural complexity in agricultural soils. Soil and Tillage Research, 79(1), 1-6. https://doi.org/10.1016/j.still.2004.04.001

Chapin, F. S., Kofinas, G. P., \& Folke, C. (Eds.). (2009). Principles of Ecosystem Stewardship: Resilience-Based Natural Resource Management in a Changing World. Springer, New York, USA. https://doi.org/10.1007/ 978-0-387-73033-2

Chappell, M. J., \& LaValle, L. A. (2011). Food security and biodiversity: Can we have both? An agroecological analysis. Agriculture and Human Values, 28(1), 3-26. https://doi.org/10.1007/s10460-009-9251-4

Connor, D. J. (2008). Organic agriculture cannot feed the world. Field Crops Research, 106(2), $187-190$. https://doi.org/10.1016/j.fcr.2007.11.010

Crowder, D. W., \& Reganold, J. P. (2015). Financial competitiveness of organic agriculture on a global scale. Proceedings of the National Academy of Sciences of the United States of America, 112(24), 7611-7616. https://doi.org/10.1073/pnas.1423674112

Cullather, N. (2010). The Hungry World: America's Cold War Battle Against Poverty in Asia. Harvard University Press, USA.

Dale, V. H., \& Polasky, S. (2007) Measures of the effects of agricultural practices on ecosystem services. Ecological Economics, 64, 86-96. https://doi.org/10.1016/j.ecolecon.2007.05.009

Dale, V. H., Kline, K. L., Kaffka, S. R., \& Langeveld, J. W. A. (2013). A landscape perspective on sustainability of agricultural systems. Landscape Ecology, 28(6), 1111-1123. https://doi.org/10.1007/s10980-012-9814-4

Das, R. J. (2002). The green revolution and poverty: A theoretical and empirical examination of the relation between technology and society. Geoforum, 33(1), 55-72. https://doi.org/10.1016/S0016-7185(01)00006-9

Dasgupta, P., Morton, J. F., Dodman, D., Karapinar, B., Meza, F., Rivera-Ferre, M. G., ... Vincent, K. E. (2014). Rural areas. In C. B. Field, V. R. Barros, D. J. Dokken, K. J. Mach, M. D. Mastrandrea, T. E. Bilir, ... L. L. White (Eds.), Climate Change 2014: Impacts, Adaptation, and Vulnerability. Part A: Global and Sectoral Aspects (pp. 613-657). Contribution of Working Group II to the Fifth Assessment Report of the Intergovernmental Panel on Climate Change. Cambridge University Press, Cambridge, United Kingdom and New York, NY, USA. Retrieved October 16, 2017, from http://www.ipcc.ch/pdf/assessment-report/ ar5/wg2/WGIIAR5-Chap9_FINAL.pdf

de Ponti, T., Rijk, B., \& van Ittersum, M. K. (2012). The crop yield gap between organic and conventional agriculture. Agricultural Systems, 108, 1-9. https://doi.org/10.1016/j.agsy.2011.12.004

Deguine, J. P., Ferron, P., \& Russell, D. (2008). Sustainable pest management for cotton production: A review. Agronomy for Sustainable Development, 28(1), 113-137. https://doi.org/10.1051/agro:2007042

Delbridge, T. A., Fernholz, C., King, R. P., \& Lazarus, W. (2013). A whole-farm profitability analysis of organic and conventional cropping systems. Agricultural Systems, 122, 1-10. https://doi.org/10.1016/j-agsy.2013. 07.007

Devos, Y., Maeseele, P., Reheul, D., Van Speybroeck, L., \& De Waele, D. (2008). Ethics in the societal debate on genetically modified organisms: A (re)quest for Sense and Sensibility. Journal of Agricultural and Environmental Ethics, 21(1), 29-61. https://doi.org/10.1007/s 10806-007-9057-6

Diesendorf, M. (2000). Sustainability and sustainable development. In D. Dunphy, J. Benveniste, A. Griffiths, \& P. Sutton (Eds.), Sustainability: The Corporate Challenge of the 21st Century (pp. 19-37). Allen and Unwin, Sydney. 
Dimitri, C., \& Oberholtzer, L. (2009). Marketing U.S. Organic Foods: Recent Trends from Farms to Consumers. Economic Information Bulletin, 58. USDA, Economic Research Service. Retrieved October 16, 2017, from https:/www.ers.usda.gov/webdocs/publications/44430/11008_eib58_reportsummary_1_.pdf?v=41055

Dovers, S., \& Hussey, K. (2013). Environment and Sustainability: A Policy Handbook. The Federation Press, Sydney, Australia.

EU. (2015). European Commission, Agriculture and Rural Development, Agri-Environment Measures. Retrieved October 16, 2017, from http://ec.europa.eu/agriculture/envir/measures/index_en.htm

Ewel, J. J. (1999). Natural systems as models for the design of sustainable systems of land use. Agroforestry Systems, 45(1-3), 1-21. https://doi.org/10.1023/A:1006219721151

Fanin, N., Hattenschwiler, S., \& Fromin, N. (2014). Litter fingerprint on microbial biomass, activity, and community structure in underlying soil. Plant Soil, 379(1-2), 79-91. https://doi.org/10.1007/s11104014-2051-7

FAO. (1996). Towards a New Green Revolution. World Food Summit: Food for All. Natural Resources Management and Environment Department. Retrieved October 16, 2017, from http://www.fao.org/docrep/ x0262e/x0262e06.htm

FAO. (2001a). Codex Alimentarius-Organically Produced Foods. Joint FAO/WHO Food Standards Programme CODEX ALIMENTARIUS COMMISSION (2nd ed., Section 2), Description and Definitions. Rome, Italy. Retrieved October 16, 2017, from http://www.fao.org/3/a-a0369e.pdf

FAO. (2001b). World Soil Research Reports, Notes on the major soils of the world. Book written in collaboration with Wageningen Agricultural University (Wageningen, The Netherlands), the International Institute for Aerospace Survey and Earth Sciences (ITC, Enschede, The Netherlands), the International Soil Reference and Information Centre (ISRIC, Wageningen, The Netherlands), the Faculty of Agricultural Sciences of the Katholieke Universiteit Leuven (Blegium) and FAO. Retrieved October 16, 2017, from http://www.fao.org/DOCREP/003/Y1899E/Y1899E00.htm

FAO. (2011). Global Food Losses and Food Waste: Extent, Causes and Prevention. Executive Summary, Resource document. Food and Agriculture Organization of the United Nations, Rome. Retrieved October 16, 2017, from http://www.fao.org/docrep/014/mb060e/mb060e00.pdf

FAO. (2014). Sustainability Assessment of Food and Agricultural Systems, SAFA Guidelines. Rome. Retrieved October 16, 2017, from http://www.fao.org/3/a-i3957e.pdf

Feber, R. E., Johnson, P. J., Bell, J. R., Chamberlain, D. E., Firbank, L. G., Fuller, R. J., ... Macdonald, D. W. (2015). Organic Farming: Biodiversity Impacts Can Depend on Dispersal Characteristics and Landscape Context. PLoS One, 10(8), e0135921. https://doi.org/10.1371/journal.pone.0135921

Ferguson, R. S., \& Lovell, S. T. (2014). Permaculture for agroecology: Design, movement, practice, and worldview: A review. Agronomy for Sustainable Development, 34(2), 251-274. https://oi.org/10.1007/ s13593-013-0181-6

Figuerola, E. L. M., Guerrero, L. D., Rosa, S. M., Simonetti, L., Duval, M. E., Galantini, J. A., ... Erijman, L. (2012). Bacterial Indicator of Agricultural Management for Soil under No-Till Crop Production. PLoS One, 7(11). https://doi.org/10.1271/journal.pone.0051075

Filson, G. C. (2004). Intensive agriculture and sustainability: A farming system analysis. UBC Press, Ontario, Canada.

Fisher, J., Tozer, P., \& Abrecht, D. (2012). Livestock in no-till cropping systems-A story of trade-offs. Animal Production Science, 52(4), 197-214. https://doi.org/10.1071/AN11123

Flannery, T. F. (1994). The Future Eaters: An Ecological History of the Australasian Lands and People. Read New Holland Publishers, Australia.

Foley, J. A., Ramankutty, N., Brauman, K. A., Cassidy, E. S., Gerber, J. S., Johnston, M., ... Zaaks, D. P. M. (2011). Solutions for a cultivated planet. Nature, 478(7369), 337-342. https://doi.org/10.1038/nature10452

Foresight. (2011). The Future of Food and Farming_Final Project Report. The Government Office for Science, London. Retrieved October 16, 2017, from https://www.gov.uk/government/uploads/system/uploads/ attachment_data/file/288329/11-546-future-of-food-and-farming-report.pdf 
Gabriel, D., Sait, S. M., Kunin, W. E., \& Benton, T. G. (2013). Food production vs. biodiversity: Comparing organic and conventional agriculture. Journal of Applied Ecology, 50(2), 355-364. https://doi.org/10.1111/ 1365-2664.12035

Gagliardi, B., \& Pettigrove, V. (2013). Removal of intensive agriculture from the landscape improves aquatic ecosystem health. Agriculture, Ecosystems and Environment, 176, 108. https://doi.org/10.1016/j.agee.2013. 05.020

Gammage, B. (2011). The Biggest Estate on Earth: How Aboriginies Made Australia. Allen and Unwin, Australia.

Gardiner, B., \& Reid, N. (2010). Sustainable Livestock Production (Book Chapter). In D. Cottle (Ed.), International Sheep and Wool Handbook. Nottingham University Press. UK.

Garrity, D. P., Akinnifesi, F. K., Ajayi, O. C., Weldesemayat, S. G., Mowo, J. G., Kalinganire, A., ... Bayala, J. (2010). Evergreen Agriculture: A robust approach to sustainable food security in Africa. Food Security, 2(3), 197-214. https://doi.org/10.1007/s12571-010-0070-7

Gibson, R. H., Pearce, S., Morris, R. J., Symondson, W. O. C., \& Memmott, J. (2007). Plant diversity and land use under organic and conventional agriculture: A whole-farm approach. Journal of Applied Ecology, 44(4), 792-803. https://doi.org/10.1111/j.1365-2664.2007.01292.x

Girvan, M. S., Campbell, C. D., Killham, K., Prosser, J. I., \& Glover, L. A. (2005). Bacterial diversity promotes community stability and functional resilience after perturbation, Environmental Microbiology, 7(3), 301-313. https://doi.org/10.1111/j.1462-2920.2005.00695.x

Glendining, M. J., Dailey, A. G., Williams, A. G., van Evert, F. K., Goulding, K. W. T., \& Whitmore, A. T. (2009). Is it possible to increase the sustainability of arable and ruminant agriculture by reducing inputs? Agricultural Systems, 99(2-3), 117-125. https://doi.org/10.1016/j.agsy.2008.11.001

Gliessman, S. (2013). Agroecology: Growing the Roots of Resistance. Agroecology and Sustainable Food Systems, 37(1), S1, 19-31.

Godfray, H. C. J., Beddington, J. R., Crute, I. R., Haddad, L., Lawrence, D., Muir, J. F., ... Toulmin, C. (2010). Food Security: The Challenge of Feeding 9 Billion People. Science, 327, 812-818. https://doi.org/10.1126/ science. 1185383

Goldberger, J. R. (2011). Conventionalization, civic engagement, and the sustainability of organic agriculture. Journal of Rural Studies, 27(3), 288-296. https://doi.org/10.1016/j.rustud.2011.03.002

Gomiero, T., Pimentel, D., \& Paoletti, M. G. (2011). Environmental Impact of Different Agricultural Management Practices: Conventional v Organic Agriculture. Critical Reviews in Plant Sciences, 30(1-2), 95-124. https://doi.org/10.1080/07352689.2011.554355

Grasswitz, T. R., \& James, D. G. (2009). Influence of hop yard ground flora on invertebrate pests of hops and their natural enemies. Journal of Applied Entomology, 133(3), 210-221. https://doi.org/10.1111/j.1439-0418. 2008.01336.x

Hafla, A. N., MacAdam, J. W., \& Soder, K. J. (2013) Sustainability of US Organic Beef and Dairy Production Systems: Soil, Plant and Cattle Interactions. Sustainability, 5(7), 3009-3034. https://oi.org/10.3390/ su5073009

Halloran, J. M., \& Archer, D. W. (2008). External economic drivers and US agricultural production systems. Renewable Agriculture and Food Systems, 23(4), 296-303. https://doi.org/10.1017/S1742170508002287

Halteman, M. C. (2011). Varieties of Harm to Animals in Industrial Farming. Journal of Animal Ethics, 1(2), 122-131. https://doi.org/10.5406/janimalethics.1.2.0122

Hamblin, A. (2009). Policy directions for agricultural land use in Australia and other post-industrial economies. Land Use Policy, 26(4), 1195-1204. https://doi.org/10.1016/j.landusepol.2009.01.002

Hansen, J. W. (1996). Is Agricultural Sustainability a Useful Concept? Agricultural Systems, 50(2), 117-143. https://doi.org/10.1016/0308-521X(95)00011-S

Hardeman, E., \& Jochemsen, H. (2012). Are There Ideological Aspects to the Modernization of Agriculture? Journal of Agricultural and Environmental Ethics, 25(5), 657-674. https://oi.org/10.1007/s10806011-9331-5 
Havlicek, E. (2012). Soil biodiversity and bioindication: From complex thinking to simple acting. European Journal of Soil Biology, 49(SI), 80-84. https://doi.org/10.1016/j.ejsobi.2012.01.009

Heckman, J. R. (2013). Soil Fertility Management a Century Ago in "Farmers of Forty Centuries". Sustainability, 5, 2796-2801. https://doi.org/10.3390/su5062796

Helfrich, M., Ludwig, B., Potthoff, M., \& Flessa, H. (2008). Effect of litter quality and soil fungi on macroaggregate dynamics and associated partitioning of litter carbon and nitrogen. Soil Biology and Biochemistry, 40(7), 1823-1835. https://doi.org/10.1016/j.soilbio.2008.03.006

Hole, D. G., Perkins, A. J., Wilson, J. D., Alexander, I. H., Grice, P. V., \& Evans, A. D. (2005). Does organic farming benefit biodiversity? Biological Conservation, 122(1), 113-130. https://doi.org/10.1016/j.biocon. 2004.07.018

Holt-Gimenez, E. (2002). Measuring farms agroecological resistance to Hurricane Mitch in Nicaragua: a case study in participatory, sustainable land management impact monitoring. Agriculture Ecosystems and Environment, 93(1-3), 87-105. https://doi.org/10.1016/S0167-8809(02)00006-3

Holzschuh, A., Steffan-Dewenter, I., Kleijn, D., \& Tscharntke, T. (2007). Diversity of flower-visiting bees in cereal fields: Effects of farming system, landscape composition and regional context. Journal of Applied Ecology, 44(1), 41-49. https://doi.org/10.1111/j.1365-2664.2006.2006.01259.x

Horrigan, L., Lawrence, R. S., \& Walker, P. (2002). How sustainable agriculture can address the environmental and human health harms of industrial agriculture. Environmental Health Perspectives, 110(5), 445-459. https://doi.org/10.1289/ehp.02110445

Howley, P., Donoghue, C. O., \& Hynes, S. (2012). Exploring public preferences for traditional farming landscapes. Landscape and Urban Planning, 104(1), 66-74. https://doi.org/10.1016/j.landurbplan.2011.09.006

Janzen, D. H. (1986). Chihuahuan Desert Nopaleras_-Defaunated Big Mammal Vegetation. Annual Review of Ecology and Systematics, 17, 595-636. https://doi.org/10.1146/annurev.es.17.110186.003115

Kaine, G., \& Cowan, L. (2011). Using General Systems Theory to Understand How Farmers Manage Variability. Systems Research and Behavioral Science, 28(3), 231-244. https://doi.org/10.1002/sres.1073

Kaltenborn, B. P., \& Bjerke, T. (2002). Associations between environmental value orientations and landscape preferences. Landscape and Urban Planning, 59(1), 1-11. https://doi.org/10.1016/S0169-2046(01)00243-2

Kevan, P. G., \& Phillips, T. P. (2001). The economic impacts of pollinator declines: An approach to assessing the consequences. Conservation Ecology, 5(1). Retrieved October 16, 2017, from http://www.ecologyand society.org/vol5/iss 1/art8

Klerkx, L., Aarts, N., \& Leeuwis, C. (2010). Adaptive management in agricultural innovation systems: The interactions between innovation networks and their environment. Agricultural Systems, 103(6), 390-400. https://doi.org/10.1016/j.agsy.2010.03.012

Knoblauch, W. A, Brown, R., \& Braster, M. (1990). Organic field crop production: A review of the economic literature. Ithaca, NY: Agriculture Experimental Research, Department of Agricultural Economics, Cornell University. Retrieved October 16, 2017, from http://publications.dyson.cornell.edu/research/researchpdf/rb/ 1990/Cornell-Dyson-rb9010.pdf

Kolkman, I., Opsomer, G., Aerts, S., Hoflack, G., Laevens, H., \& Lips, D. (2010). Analysis of body measurements of newborn purebred Belgian Blue calves. Animal, 4(5), 661-671. https://doi.org/10.1017/S17517311 09991558

Kornegay, J. L., Harwood, R. R., Batie, S. S., Bucks, D., Flora, C. B., Hanson, J., ... Willis, P. (2010). In P. T. Whitacre, (Ed.), Towards Sustainable Agricultural Systems in the $21^{\text {st }}$ Century (Chapter 1). Committee on Twenty-First Century Systems Agriculture. The National Academies Press, Washington DC. USA.

Krebs, C. J. (2001). Ecology: the experimental analysis of distribution and abundance (5th ed.). Addison Wesley Longman, Inc. San Francisco, California, USA.

Kremen, C. (2015). Reframing the land-sparing/land-sharing debate for biodiversity conservation. Year in Ecology and Conservation Biology, Book Series: Annals of New York Academy of Sciences, 1355, 52-76. https://doi.org/10.1111/nyas.12845

Kremen, C., Williams, N. M., \& Thorp, R. W. (2002). Crop pollination from native bees at risk from agricultural intensification. Proceedings of the National Academy of Sciences of the United States of America, 99(26), 
16812-16816. https://doi.org/10.1073/pnas.262413599

Laible, G., Wei, J. W., \& Wagner, S. (2015). Improving livestock for agriculture-technological progress from random trans genesis to precision genome editing heralds a new era. Biotechnology Journal, 10, 109-120. https://doi.org/10.1002/biot.201400193

Lal, R. (2011). Sequestering carbon in soils of agro-ecosystems. Food Policy, 36(S1), S33-S39. https://doi.org/ 10.1016/j.foodpol.2010.12.001

Lal, R. (2013). Enhancing ecosystem services with no-til. Renewable Agriculture and Food Systems, 28(2), 102-114. https://doi.org/10.1017/S1742170512000452

Leifeld, J. (2012). How sustainable is organic farming? Agriculture, Ecosystems and Environment, 150, $121-122$. https://doi.org/10.1016/j.agee.2012.01.020

Leithold, G., Huelsbergen, K.-J., \& Brock, C. (2015). Organic matter returns to soils must be higher under organic compared to conventional farming. Journal of Plant Nutrition and Soil Science, 178(1), 4-12. https://doi.org/10.1002/jpln/201400133

Lemaire, G., Franzluebbers, A., de Faccio Carvalho, P. C., \& Dedieu, B. (2014). Integrated crop-livestock systems: Strategies to achieve synergy between agricultural production and environmental quality. Agriculture, Ecosystems and Environment, 190(SI), 4-8. https://doi.org/10.1016/j.agee.2013.08.009

Letoureau, D. K., \& Bothwell, S. G. (2008). Comparison of Organic and Conventional Farms: Challenging Ecologists to Make Biodiversity Functional. Frontiers in Ecology and the Environment, 6(8), 430-438. https://doi.org/10.1890/070081

Ludwig, D. (2002). In L. H. Gunderson \& C. S. Holling (Eds.), Panarchy: Understanding Transformations in Human and Natural Systems (Chapter 1, p. 16). Island Press, Washington.

MacRae, R. J., Frick, B., \& Martin, R. C. (2007). Economic and social impacts of organic production systems. Canadian Journal of Plant Science, 87(5), 1037-1044. https://doi.org/10.4141/CJPS07135

Malezieux, E. (2012). Designing cropping systems from nature. Agronomy for Sustainable Development, 32(1), 15-29. https://doi.org/10.1007/s13593-011-0027-z

Malezieux, E., Crozat, Y., Dupraz, C., Laurans, M., Makowski, D., Ozier-Lafontaine, H., ... Valantin-Morison, M. (2009). Mixing plant species in cropping systems: Concepts, tools and models: A review. Agronomy for Sustainable Development, 29(1), 43-62. https://doi.org/10.1051/agro:2007057

Martini, E. A., Jeffrey, S. Buyer, J. S., Bryant, D. C., Hartz, T. K., \& Denison, R. F. (2004). Yield increases during the organic transition: improving soil quality or increasing experience? Field Crops Research, 86(2-3), 255-266. https://doi.org/10.1016/j.fcr.2003.09.002

McColl, K. A., Clarke, B., \& Doran, T. J. (2013). Role of genetically engineered animals in future food production. Australian Veterinary Journal, 91(3), 113-117. https://doi.org/10.1111/avj.12024

Millar, G. D., \& Badgery, W. B. (2009). Pasture cropping: A new approach to integrate crop and livestock farming systems. Animal Production Science, 49(9-10), 777-787. https://doi.org/10.1071/AN09017

Montgomery, D. R. (2007). Soil erosion and agricultural sustainability. Proceedings of the National Academy of Sciences, 4(33), 13268-13272. https://doi.org/10.1073/pnas.o611508104

Morris, E. J. (2011). A semi-quantitative approach to GMO risk-benefit analysis. Transgenic Research, 20(5), 1055-1071. https://doi.org/10.1007/s11248-010-9489-8

Nielsen, U. N., Ayres, E., Wall, D. H., \& Bardgett, R. D. (2011). Soil biodiversity and carbon cycling: A review and synthesis of studies examining diversity-function relationships. European Journal of Soil Science, 62(1), 105-116. https://doi.org/10.1111/j/1365-2389.2010.0314.x

Norris, C., Hobson, P., \& Ibisch, P. L. (2012). Microclimate and vegetation function as indicators of forest thermodynamic efficiency. Journal of Applied Ecology, 49(3), 563-570. https://doi.org/10.111/j.1365-2664. 2011.02084.x

NRC. (2010). Towards Sustainable Agriculture in the $21^{\text {st }}$ Century. Committee on Twenty-First Century Systems Agriculture, Board on Agriculture and Natural Resources, Division on Earth and Life Studies, National Research Council of the National Academies. The National Academies Press, Washington DC.

Obach, B. K., \& Tobin, K. (2014). Civic agriculture and community engagement. Agriculture and Human Values, 31(2), 307-322. https://doi.org/10.1007/s10460-013-9477-z 
OECD. (2013). Policy Instruments to Support Green Growth in Agriculture. The Organisation for Economic Development. OECD Publishing. Retrieved October 16, 2017, from http://www.oecdilibrary.org/docserver/ download $/ 5113081$ e.pdf? expires $=1458781195 \& \mathrm{id}=\mathrm{id} \&$ accname $=$ ocid195150\&checksum $=6 \mathrm{E} 5 \mathrm{FC} 8 \mathrm{C} 6 \mathrm{~F} 44 \mathrm{~F}$ EE25660B53E0E46DACD1

Otero, I., Marull, J., Tello, E., Diana, G. L., Pons, M., Coll, F., \& Boada, M. (2015). Land abandonment, landscape, and biodiversity: Questioning the restorative character of the forest transition in the Mediterranean. Ecology and Society, 20(2), Article 7. https://doi.org/10.5751/ES-07378-200207

Oxford English Dictionary. (2016). ISBN: 9780199571123.

Pannell, D. J. (1999). Social and economic challenges in the development of complex farming systems. Agroforestry Systems, 45(1-3), 393-409.

Parrott, L. (2010). Measuring ecological complexity. Ecological Indicators, 10, 1069-1076. https://doi.org/ 10.1016/j.ecolind.2010.03.014

Pascoe, B. (2014). Dark Emu. Magabala Books, Australia.

Phalan, B., Onial, M., Balmford, A., \& Green, R. E. (2011). Reconciling Food Production and Biodiversity Conservation: Land Sharing and Land Sparing Combined. Science, 333(6047), 1289-1291. https://doi.org/ 10.1126/science. 1208742

Plequezuelo, C. R. R., Zuazo, V. H. D., Raya, A. M., Martinez, J. F. R., \& Rodrigues, B. C. (2009). High reduction of erosion and nutrient losses by decreasing harvest intensity of lavender grown on slopes. Agronomy for Sustainable Development, 29(2), 363-370. https://doi.org/10.1051/agro:2008043

Powlson, D. S., Gregory, P. J., Whalley, W. R., Quinton, J. N., Hopkins, D. W., Whitmore, A. P., ... Goulding, K. W. T. (2011). Soil management in relation to sustainable agriculture and ecosystem services. Food Policy, 36(S1), S72-S87. https://doi.org/10.1016/j.foodpol.2010.11.025

Pretty, J. N. (2008). Agricultural sustainability: Concepts, principles and evidence. Philosophical Transactions of the Royal Society of Biological Sciences, 363(1491), 447-467. https://doi.org/10.1098/rstb.2007.2163

Pretty, J. N., Noble, A. D., Bossio, D., Dixon, J., Hine, R. E., de Vries, F. W. T. P., \& Morison, J. I. L. (2006). Resource-conserving agriculture increases yields in developing countries. Environmental Science and Technology, 40(4), 1114-1119. https://doi.org/10.1021/es051670d

Pulido, J. S., \& Bocco, G. (2003). The traditional farming system of a Mexican indigenous community: The case of Nuevo San Juan Parangaricutiro, Michoacan, Mexico. Geoderma, 111(3-4), 249-265. https://doi.org/ 10.1016/S0016-7061(02)00267-7

RaboBank. (2009). Farm and Ranch Survey. Referenced in Delta Farm Press. Retrieved February 1, 2011, from https:/www.rabobankamerica.com/public/documents/pdfs/RaboFarmandRanchSurvey_SustainableAg.pdf and Retrieved October 16, 2017, from http:/www.deltafarmpress.com/management/farmers-use-moresustainable-practices

Reganold, J. P., \& Wachter, J. M. (2016). Organic agriculture in the twenty-first century. Nature (Plants), 2(Article Number 15221), 1-8. https://doi.org/10.1038/NPlants.2015.221

Rigby, D., \& Caceres, D. (2001). Organic farming and the sustainability of agricultural systems. Agricultural Systems, 68(1), 21-40. Retrieved October 16, 2017, from http:/www.sciencedirect.com/science/article/pii/ S0308521X00000603

Roger-Estrade, J., Anger, C., Bertrand, M., \& Richard, G. (2010). Tillage and soil ecology: Partners for sustainable agriculture. Soil and Tillage Research, 111(1), 33-40, SI. https://doi.org/10.1016/j.still. 2010.08.010

Röling, N. G., \& Wagemakers, M. A. E. (1998). A new practice: Facilitating sustainable agriculture. In N. G. Röling \& M. A. E. Wagemakers (Eds.), Facilitating sustainable agriculture: Participatory learning and adaptive management in times of environmental uncertainty (pp. 3-22). Cambridge University Press, Cambridge.

Rosset, P. M., Sosa, B. M., Roque, A. M., \& Lozano, D. R. A. (2011). The Campesino-to-Campesino agroecology movement of ANAP in Cuba: Social process methodology in the construction of sustainable peasant agriculture and food sovereignty. The Journal of Peasant Studies, 38(1), 161-191. https://doi.org/10.1080/ 03066150.2010 .538584 
Rudel, T. K., Schneider, L., Uriarte, M., Turner, B. L. II, DeFries, R., Lawrence, D., ... Grau, R. (2009). Agricultural intensification and changes in cultivated areas, 1970-2005. Proceedings of the National Academy of Sciences of the United States of America, 106(49), 20675-20680. https://doi.org/10.1073/pnas. 0812540106

Scherr, S. J., \& McNeely, J. A. (2008). Biodiversity conservation and agricultural sustainability: Towards a new paradigm of "ecoagriculture" landscapes. Philosophical Transactions of the Royal Society B-Biological Sciences, 363(1491), 477-494. https://doi.org/10.1098/rstb.2007.2165

Schmidt, M. W. I., Torn, M. S., Abiven, S., Dittmar, T., Guggenberger, G., Janssens, I. A., ... Trumbore, S. E. (2011). Persistence of soil organic matter as an ecosystem property. Nature, 478(7367), 49-56. https://doi.org/10.1038/nature10386

Schneider, E. D., \& Kay, J. J. (1994). Life as a manifestation of the $2^{\text {nd }}$ Law of Thermodynamics. Mathematical and Computer Modelling, 19(6-8), 25-48. https://doi.org/10.1016/0895-7177(94)90188-0

Schneider, M. K., Luescher, G., Jeanneret, P., Arndorfer, M., Ammari, Y., Bailey, D., ... Herzog, F. (2014). Gains to species diversity in organically farmed fields are not propagated at the farm level. Nature Communications, 5, Article 4151. https://doi.org/10.1038/ncomms5151

Seufert, V., Ramankutty, N., \& Foley, J. A. (2012). Comparing the yields of organic and conventional agriculture. Nature, 485(7397), 229-232. https://doi.org/10.1038/nature11069

Simon, H. A. (1957). Administrative Behavior: A Study of Decision-Making Processes in Administrative Organization (2nd ed.). Library of Congress Catalogue Card Number: 57-5627. Macmillan, New York, USA.

Singh, J. S., Pandey, V. C., \& Singh, D. P. (2011). Efficient soil microorganisms: A new dimension for sustainable agriculture and environmental development. Agriculture, Ecosystems and Environment, 140(3-4), 339-353. https://doi.org/10.1016/j.agee.2011.01.017

Smith-Spangler, C., Brandeau, M. L., Hunter, B. A., Bavinger, J. C., Pearson, M., Eschbach, P. J., ... Bravata, D. M. (2012). Are organic foods safer or healthier than conventional alternatives? A Systematic Review. Annals of Internal Medicine, 157(5), 348-U112. https://doi.org/10.7326/0003-4819-157-5-20120904000007

Sumner, J., Mair, H., \& Nelson, E. (2010). Putting the culture back into agriculture: Civic engagement, community and the celebration of local food. International Journal of Agricultural Sustainability, 8(1-2), 54-61. https://doi.org/10.3763/ijas.2009.0454

Te Pas, C. M., \& Rees, R. M. (2014). Analysis of Differences in Productivity, Profitability and Soil Fertility Between Organic and Conventional Cropping Systems in the Tropics and Sub-tropics. Journal of Integrative Agriculture, 13(10), 2299-2310. https://doi.org/10.1016/S2095-3119(14)60786-3

Thornton, A. (2009). Pastures of plenty? Land rights and community-based agriculture in Peddie, a former homeland town in South Africa. Applied Geography, 29(1), 12-20. https://doi.org/10.1016/j.apgeog.2008. 06.001

Tomlinson, S., Arnall, S. G., Munn, A., Bradshaw, S. D., Maloney, S. K., Dixon, K. W., \& Didham, R. K. (2014). Applications and implications of ecological energetics. Trends in Ecology and Evolution, 29(5), $280-290$. https://doi.org/10.1016/j.tree.2014.03.003

Tscharntke, T., Klein, A. M., Kruess, A., Steffan-Dewenter, I., \& Thies, C. (2005). Landscape perspectives on agricultural intensification and biodiversity-Ecosystem service management. Ecology Letters, 8(8), 857-874. https://doi.org/10.1111/j.1461-0248.2005.00782.x

Tu, C., Louws, F. J., Creamer, N. G., Mueller, J. P., Brownie, C., Fager, K., ... Hu, S. J. (2006). Responses of soil microbial biomass and $\mathrm{N}$ availability to transition strategies from conventional to organic farming systems. Agriculture Ecosystems and Environment, 113(1-4), 206-216. https://doi.org/10.1016/j.agee,2005.09.013

Tuck, S., Winqvist, C., Mota, F., Ahnstrom, J., Turnbull, L. A., \& Bengtsson, J. (2014). Land-use intensity and the effects of organic farming on biodiversity: A hierarchical meta-analysis. Journal of Applied Ecology, 51(3), 746-755. https://doi.org/10.1111/1365.2664.12219

UN. (2005), United Nations Environment Program, Millennium Ecosystem Assessment, 2005. Ecosystems and Human Well-being: Biodiversity Synthesis. World Resources Institute, Washington, DC. Retrieved October 16, 2017, from http://www.unep.org/maweb/documents/document.354.aspx.pdf 
UN. (2008). United Nations, Promotion and protection of all human rights, civil, political, economic and social and cultural rights, including the right to development. Report of the Special Rapporteur on the right to food, Jean Ziegler, Human Rights Council (A/HRC/7/5). Geneva: United Nations. Retrieved October 16, 2017 , from http:/www2.ohchr.org/english/bodies/hrcouncil/docs/7session/A-HRC-7-5.doc

USDA. (2007). United States Department of Agriculture, National Agriculture Library, Alternative Farming Systems Information Center, Publications. Sustainable Agriculture: Terms and Definitions. Special Reference Briefs Series No. SRB99-02. Retrieved October 16, 2017, from http://www.nal.usda.gov/ afsic/pubs/terms/srb9902.shtml

Vencill, W. K., Nichols, R. L., Webster, T. M., Soteres, J. K., Mallory-Smith, C., Burgos, N. R., ... McClelland, M. R. (2012). Herbicide Resistance: Toward an Understanding of Resistance Development and the Impact of Herbicide-Resistant Crops. Weed Science, 60(S1), 2-30. https://doi.org/10.1614/WS-D-11-00206.1

Vieweger, A., \& Doring, T. F. (2015). Assessing health in agriculture-Towards a common research framework for soils, plants, animals, humans and ecosystems. Journal of the Science of Food and Agriculture, 95(3), 438-446. https://doi.org/10.1002/jsfa.6708

Villegas, J. C., Breshears, D. D., Zou, C. B., \& Law, D. J. (2010). Ecohydrological controls of soil evaporation in deciduous drylands: How the hierarchical effects of litter, patch and vegetation mosaic cover interact with phenology and season. Journal of Arid Environments, 74(5), 595-602. https://doi.org/10.1016/j.jaridenv. 2009.09.028

Vogl, C. R., Kilcher, L., \& Schmidt, H. (2005). Are Standards and Regulations of Organic Farming Moving Away from Small Farmers' Knowledge? Journal of Sustainable Agriculture, 26(1), 5-26. https://doi.org/ 10.1300/j064v26n01_03

Walker, B., \& Salt, D. (2012). Resilience Practice: Building Capacity to Absorb Disturbance and Maintain Function (1st ed.). Island Press. https://doi.org/10.5822/978-1-61091-231-0

Waltz, E. (2009). Battlefield, Nature, 461(7260), 27-32. https://doi.org/10.1038/461027a

Watson, C. A., Oborn, I., Eriksen, J., \& Edwards, A. C. (2005). Perspectives on nutrient management in mixed farming systems. Soil Use and Management, 21(S1), 132-140. https://doi.org/10.1079/SUM2005304

Weiner, J. (2003). Ecology-The science of agriculture in the $21^{\text {st }}$ century. Journal of Agricultural Science, 141, 367-377. https://doi.org/10.1017/S0021859603003605

Wezel, A., Casagrande, M., Celette, F., Vian, J. F., Ferrer, A., \& Peigne, J. (2014). Agroecological practices for sustainable agriculture: A review. Agronomy for Sustainable Development, 34(1), 1-20. https://doi.org/ $10.1007 / \mathrm{s} 13593-013-0180-7$

Wheeler, M. B., Walters, E. M., \& Clark, S. G. (2003). Transgenic animals in biomedicine and agriculture: Outlook for the future. Animal Reproduction Science, 79(3-4), 265-289. https://doi.org/10.1016/ S0378-4320(03)00168-4

Willer, H., \& Lernoud, J. (2015). The World of Organic Agriculture. Statistics and Emerging Trends 2015. FiBL, Frick, and, IFOAM-Organics International, Bonn. Retrieved October 16, 2017, from http://www.organicworld.net/yearbook/yearbook2015.html

Windfuhr, M., \& Jonsen, J. (2005). Food Sovereignty: Towards Democracy in Localised Food System. ITDG Publishing, Chippenday, Wilshire, UK.

Winqvist, C., Ahnstrom, J., \& Bengtsson, J. (2012). Effects of organic farming on biodiversity and ecosystem services: taking landscape complexity into account. Year in Ecology and Conservation Biology, Book Series: Annals of the New York Academy of Sciences, 1249, 191-203. https://doi.org/10.1111/j.1749-6632. 2011.06413.x

Woltz, J. M., Isaacs, R., \& Landis, D. A. (2012). Landscape structure and habitat management differentially influence insect natural enemies in an agricultural landscape. Agriculture, Ecosystems and Environment, 152, 40-49. https://doi.org/10.1016/j.agee.2012.02.008

Wratten, S. D., Gillespie, M., Decourtye, A., Mader, E., \& Desneux, N. (2012). Pollinator habitat enhancement: Benefits to other ecosystem services. Agriculture, Ecosystems and Environment 159, 112-122. https://doi.org/10.1016/j.agee.2012.06.020

Xu, Q. C., Fujiyama, S., \& Xu, H. L. (2011). Biological pest control by enhancing populations of natural enemies in organic farming systems. Journal of Food, Agriculture and Environment, 9(2), 455. 
Zepeda, L. (2001). Agricultural Investment, Production Capacity and Productivity. FAO, Economic and Social Development Department, Corporate Document Repository. Retrieved October 16, 2017, from http://www.fao.org/docrep/003/x9447e/x9447e03.htm

Zerda-Sarmiento, A., \& Forero-Pineda, C. (2002). Intellectual property rights over ethnic communities' knowledge. International Social Science Journal, 54(1), 99-114. https://doi.org/10.1111/1468-2451.00362

\section{Copyrights}

Copyright for this article is retained by the author(s), with first publication rights granted to the journal.

This is an open-access article distributed under the terms and conditions of the Creative Commons Attribution license (http://creativecommons.org/licenses/by/4.0/). 